\title{
ENDANGERED SPECIES PROGRAM NAVAL PETROLEUM RESERVES IN CALIFORNIA
}

\section{ANNUAL REPORT FY93}

February 1995

This report is unclassified: $\frac{e . x .}{\text { Authorized Derivative Classifier }}$

Work performed for the U. S. Departments of Energy, Naval Petroleum Reserves in California, and Chevron U.S.A. Production Company through the Nevada Operations Office under DOE Contract No. DE-AC08-93NV11265

LAS VEGAS AREA OPERATIONS P. O. Box 1912, Las Vegas, Nevada 89125

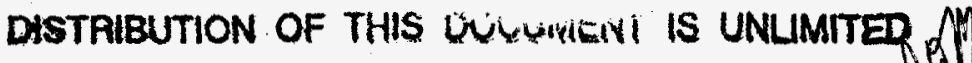

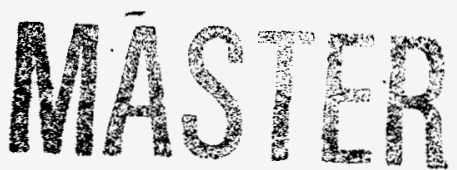




\section{DISCLAIMER}

Portions of this document may be illegible in electronic image products. Images are produced from the best available original document. 


\section{ACKNOWLEDGEMENTS}

Permission to conduct research on endangered and threatened species was granted by the U. S. Fish and Wildlife Service through permit PRT-683011, and a Memorandum of Understanding between the California Department of Fish and Game and EG\&G Energy Measurements, Inc.

This is a continuing program and interpretation of facts contained in this report may change as new data are acquired and analyzed. Results should not be cited without prior consultation. 


\section{CONTENTS}

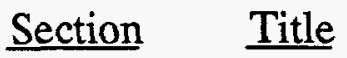

Page

ACKNOWLEDGEMENTS

1. INTRODUCTION

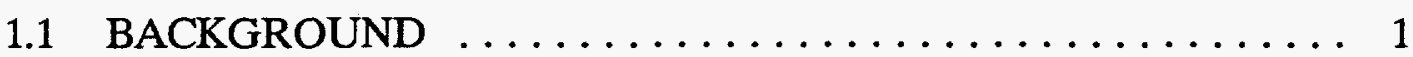

1.2 OBJECTIVES $\ldots \ldots \ldots \ldots \ldots \ldots \ldots \ldots \ldots \ldots \ldots \ldots$

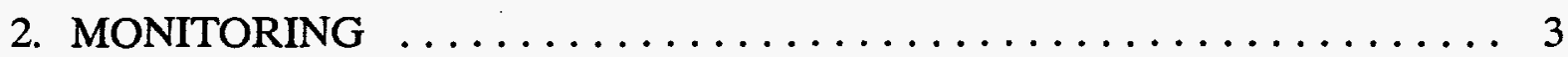

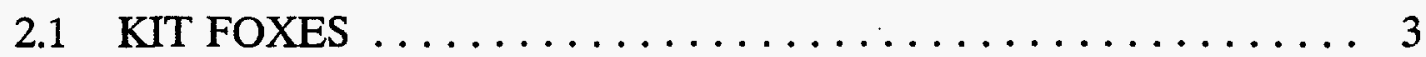

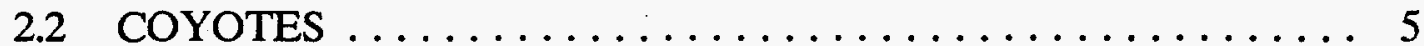

2.3 LAGOMORPHS .................... 7

2.4 SMALL MAMMALS $\ldots \ldots \ldots \ldots \ldots \ldots \ldots \ldots \ldots$

2.5 DIET OF KIT FOXES $\ldots \ldots \ldots \ldots \ldots \ldots \ldots \ldots \ldots \ldots .13$

2.6 GIANT KANGAROO RAT POPULATION MONITORING . . . 15

2.7 BLUNT-NOSED LEOPARD LIZARDS $\ldots \ldots \ldots \ldots \ldots \ldots \ldots$

2.7.1 Adult Blunt-nosed Leopard Lizards . . . . . . . . . 17

2.7.2 Juvenile Blunt-nosed Leopard Lizard Surveys .... . . . . 18

2.8 HOOVER'S WOOLY-STAR $\ldots \ldots \ldots \ldots \ldots \ldots \ldots \ldots \ldots$

2.8.1 Habitat Characterization . . . . . . . . . . . . 18

2.8.2 Hoover's Wooly-star Reference Sites . . . . . . . . . 19

2.8.3 Interim Management Guidelines . . . . . . . . . . 19

2.8.4 Experimental Studies on Practices to Conserve Hoover's

Wooly-star .................... 20

2.8.5 Monitor Reestablishment of Hoover's Wooly-star

Following Disturbance $\ldots \ldots \ldots \ldots \ldots \ldots \ldots \ldots$

2.8.5.1 Monitor Reestablishment of Hoover's Woolystar on Section 14B Source Water Well ....... 21

2.8.5.2 Monitor Reestablishment of Hoover's Woolystar on Southern California Gas Company Pipeline 
2.9 METEOROLOGICAL DATA FOR NPR-1 $\ldots \ldots \ldots \ldots \ldots 22$

2.9.1 Precipitation and Maximum/Minimum Temperatures . . . 23

2.9 .2 Relative Humidity . . . . . . . . . . . . . . . 24

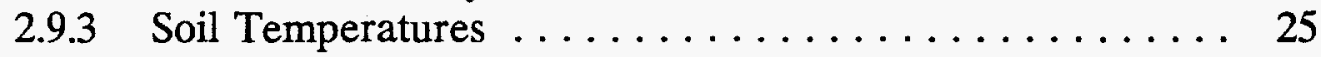

2.10 ASSESSMENT OF SPECIAL STATUS PLANT SPECIES $\ldots \ldots 26$

3. PREACTIVITY SURVEYS AND CULTURAL RESOURCE

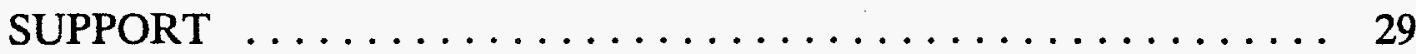

3.1 ENDANGERED SPECIES AND CULTURAL RESOURCE PREACTIVITY SURVEYS $\ldots \ldots \ldots \ldots \ldots \ldots \ldots \ldots \ldots .29$

3.2 CULTURAL RESOURCES SUPPORT $\ldots \ldots \ldots \ldots \ldots \ldots \ldots$

3.2.1 Cultural Resource Support $\ldots \ldots \ldots \ldots \ldots \ldots \ldots \ldots 30$

3.2.2 Cultural Resource Compliance .............. 31

4. HABITAT RECLAMATION AND MANAGEMENT $\ldots \ldots \ldots \ldots \ldots . . \ldots 2$

4.1 RECLAMATION OF DISTURBED LANDS $\ldots \ldots \ldots \ldots \ldots, 32$

4.2 MONITORING RECLAMATION SUCCESS $\ldots \ldots \ldots \ldots \ldots, 33$

4.2.1 Plant Establishment $\ldots \ldots \ldots \ldots \ldots \ldots \ldots \ldots \ldots \ldots$

4.2.2 Reclamation Success $\ldots \ldots \ldots \ldots \ldots \ldots \ldots \ldots \ldots$

4.2.2.1 Reclamation Success Standards . . . . . . . . 34

4.2.2.2 1988 Sites . . . . . . . . . . . . . . 35

4.2.2.3 Subsample Sites $\ldots \ldots \ldots \ldots \ldots \ldots \ldots, 36$

4.2.2.4 Research Studies ................. 37

5. RESEARCH AND DEVELOPMENT . . . . . . . . . . . . . 39

5.1 SUMMARY OF COYOTE DATA .............. 39

5.2 DISTRIBUTION AND ABUNDANCE OF KIT FOXES ON NPRC . . . . . . . . . . . . . . . . . . 42

5.3 EFFECTS OF RESEEDING BURNED AREAS ON SMALL MAMMAL AND LAGOMORPH POPULATIONS $\ldots \ldots \ldots .43$

5.3.1 Vegetation ..................... 43

5.3.2 Small Mammal Populations ................ 45

5.3.3 Lagomorph Populations ................ 47

5.4 OTHER STUDIES $\ldots \ldots \ldots \ldots \ldots \ldots \ldots \ldots \ldots \ldots \ldots$ 
6. PROGRAM ASSISTANCE $\ldots \ldots \ldots \ldots \ldots \ldots \ldots \ldots \ldots \ldots \ldots$

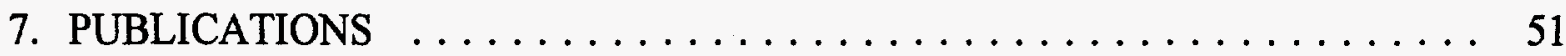




\section{TABLES}

Table Title $\underline{\text { Page }}$

1. Number of trap-nights, captures, individuals, and estimated minimum population size of San Joaquin kit foxes on the Naval Petroleum Reserves in California, during winter live-trapping sessions, 1981-1992 (NPR-1 study area) and 1983-1992 (NPR-2). . . . . . . . . . .

2. Vegetation characteristics on small mammal monitoring sites within four physiographic treatments on Naval Petroleum Reserve No. 1, Kern

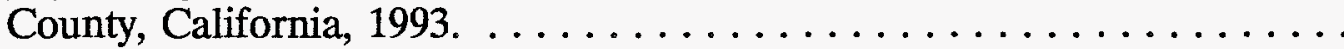

3. Small mammal captures and diversity indices within four physiographic treatments on Naval Petroleum Reserve No. 1, Kern County, California, 1993.

4. Capture probabilities for all kangaroo rats, San Joaquin antelope squirrels, and short-nosed kangaroo rats within four physiographic treatments on Naval Petroleum Reserve No. 1, Kern County, California, 1993. . . . . . . . . . . . . . . . . . . . . . . . . . . . . . . .

5. Frequency of occurrence (\%) of items found in San Joaquin kit fox scat collected during FY93, Naval Petroleum Reserves in California, Kern

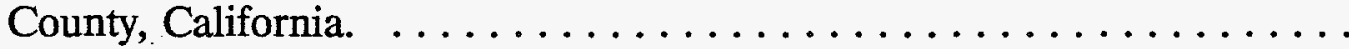

6. Number of giant kangaroo rat precincts and colonies (cluster of 2 or more precincts) observed in 20 sections of Naval Petroleum Reserve No.

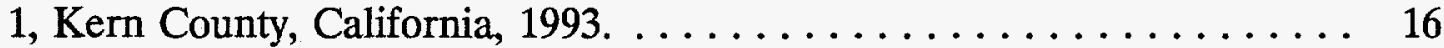

7. Average cover, density, and frequency of occurrence of Hoover's woolystar on six reference sites. Standard error is in parentheses. .........

8. Average density (no. $/ \mathrm{m}^{2}$ ) of Hoover's wooly-star on study plots near well 282 WS-14B. Standard errors are in parentheses. . . . . . . . .

9. Average density (no. $/ \mathrm{m}^{2}$ ) of Hoover's wooly-star on study plots located along Southern California Gas Company Pipeline. Standard errors are

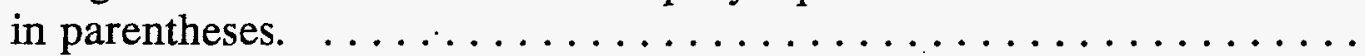


10. Average maximum and minimum temperatures $\left({ }^{\circ} \mathrm{F}\right)$ recorded during WY92 at eight stations located on Naval Petroleum Reserve No. 1, Kern County, California. .................... 24

11. Average daily maximum and minimum temperatures $\left({ }^{\circ} \mathrm{F}\right)$ and average daily maximum and minimum relative humidity $(\%)$ recorded during water year 1992 at three stations on Naval Petroleum Reserve No. 1,

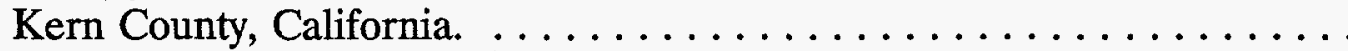

12. Soil temperatures $\left({ }^{\circ} \mathrm{F}\right)$ from January 1992 to November 1992 at three depths for open grassland and shrub understory. $\ldots \ldots \ldots \ldots \ldots \ldots$

13. List of special status plants species potentially occurring on the Naval Petroleum Reserves in California that are federal endangered species (E) or candidates for protection (C2)

14. Summary of endangered species preactivity surveys conducted during FY93 on the Naval Petroleum Reserves in California. .......... 30

15. Summary of cultural resource assessments for third-party projects completed during FY93. $\ldots \ldots \ldots \ldots \ldots \ldots \ldots \ldots \ldots \ldots \ldots \ldots$

16. Cost of revegetating disturbed lands on the Naval Petroleum Reserves

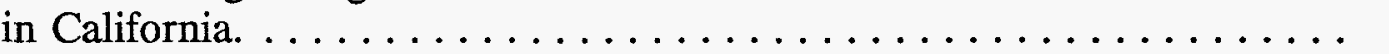

17. Results of qualitative evaluations on sites reclaimed in 1991 and 1992.

18. Average total plant cover (\%) and success standards on eight northslope and eight south-slope reference sites. Standard errors are in parentheses.

19. Average shrub density (no./ha) and success standards on eight northslope and eight south-slope reference sites. Standard errors are in parentheses.

20. Results of qualitative evaluations of 398 sites reclaimed in 1988. Standard errors are in parentheses. . . . . . . . . . . . . 36

21. Average vascular plant cover on a subsample of sites reclaimed on Naval Petroleum Reserve No. 1 between 1985 and 1992.

22. Shrub transplant survival rates on burned sites on Naval Petroleum Reserve No. 1 for 1992 and 1993. 
23. Age-class comparison of mean morphometric measurements and body mass among coyotes collected from December to March, Naval Petroleum Reserves in California, Kern County, California, 1985 1990.

24. Seasonal comparison of mean body mass for adult and yearling coyotes, Naval Petroleum Reserves in California, Kern County, California, 1985 1990.

25. Annual prevalence of antibodies to canine parvovirus (CPV), canine distemper virus (CDV), and infectious canine hepatitis virus (ICH) among coyotes at the Naval Petroleum Reserves in California, Kern County, California, from $1985-1990$. . . . . . . . . . . . . . .

26. Age-class-specific prevalence of antibodies to canine parvovirus (CPV), canine distemper virus (CDV), and infectious canine hepatitis virus (ICH) among coyotes at the Naval Petroleum Reserves in California, Kern County, California, from 1985-1990. . . . . . . . . . . . . .

27. Mean vegetative cover, density, production, and plant diversity for burn study experimental plots on Naval Petroleum Reserve No. 1, Kern County, California, Spring 1992 and 1993. . . . . . . . . . . .

28. Mean (SE) number of small mammals captured per trapline, total small mammals captured, total trap-nights and on burn study areas during November 1992, March 1993, and July 1993, Naval Petroleum Reserve No. 1, Kern County, California. 


\section{ILLUSTRATIONS}

Figure Title

1. Location of U. S. Department of Energy's Naval Petroleum Reserves in California, Kern County, California. ................ 2

2. Location of San Joaquin kit fox captures during winter 1992 trapping session, Naval Petroleum Reserves in California, Kern County, California. .......................... 3

3. Spring visitation indices for coyotes on the Naval Petroleum Reserves in California, Kern County, California, 1985-1993. . . . . . . . . . . 6

4. Lagomorphs observed on the Naval Petroleum Reserves in California during summer transects. ................... 8

5. Frequency of occurrence of lagomorph and kangaroo rat remains found in kit fox scat on the Naval Petroleum Reserves in California, FY83 -

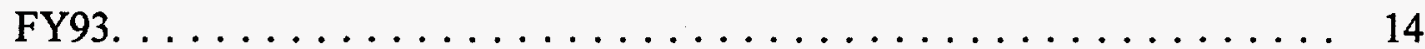

6. Average annual precipitation for water years 1981 to 1992 , Naval Petroleum Reserve No. 1, Kern County, California. 


\section{EG\&G ENERGY MEASUREMENTS, INC. APPLIED ECOLOGY DEPARTMENT}

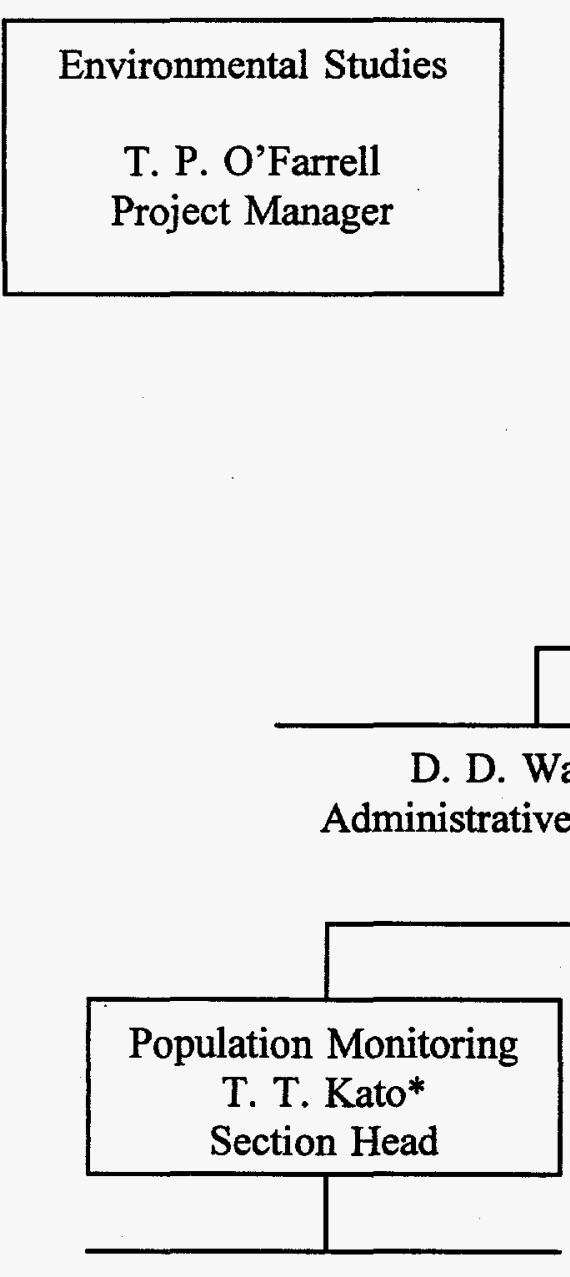

N. Frost

M. R. Otten

Applied Ecology
Department
T. T. Kato
Manager

E. L. Brodrick Secretary

D. A. Craghill Clerk

*Temporary Assignment 


\section{INTRODUCTION}

\section{$1.1 \quad$ BACKGROUND}

The Naval Petroleum Reserves in California (NPRC) are operated by the U. S. Department of Energy (DOE) and Chevron U.S.A. Production Company (CPDN). Four federally-listed endangered animal species and one federally-threatened plant species are known to occur on NPRC: San Joaquin kit fox (Vulpes velox macrotis), blunt-nosed leopard lizard (Gambelia silus), giant kangaroo rat (Dipodomys ingens), Tipton kangaroo rat (Dipodomys nitratoides nitratoides), and Hoover's wooly-star (Eriastrum hooveri). All five are protected under the Endangered Species Act of 1973 (as amended)(Public Law 93-205), which declares that it is "...the policy of Congress that all Federal departments and agencies shall seek to conserve endangered species and threatened species and shall utilize their authorities in furtherance of the purposes of the Act." DOE is also obliged to determine whether actions taken by their lessees on Naval Petroleum Reserve No. 2 (NPR-2) will have any effects on endangered species or their habitats.

Naval Petroleum Reserve No. 1 (NPR-1) and NPR-2 are located approximately 26 miles southwest Bakersfield, Kern County, California (Figure 1). NPR-1 encompasses 47,409 acres in seven townships and is located just north of NPR-2. DOE owns approximately 37,049 acres of NPR-1, while CPDN owns the remaining 10,360 acres. NPR-2 consists of 30,080 acres in five townships. DOE administers 10,400 acres on NPR-2, while the remainder is privately owned. The city of Taft occupies 1,280 acres in the southern portion of NPR-2.

\section{$1.2 \quad$ OBJECTIVES}

The major objective of the EG\&G Energy Measurements, Inc. (EG\&G/EM) Endangered Species Program on NPRC is to provide DOE with the scientific expertise necessary for compliance with the Endangered Species Act. The specific objective of this report is to summarize progress and results of the Endangered Species Program made during fiscal year 1993 (FY93). 


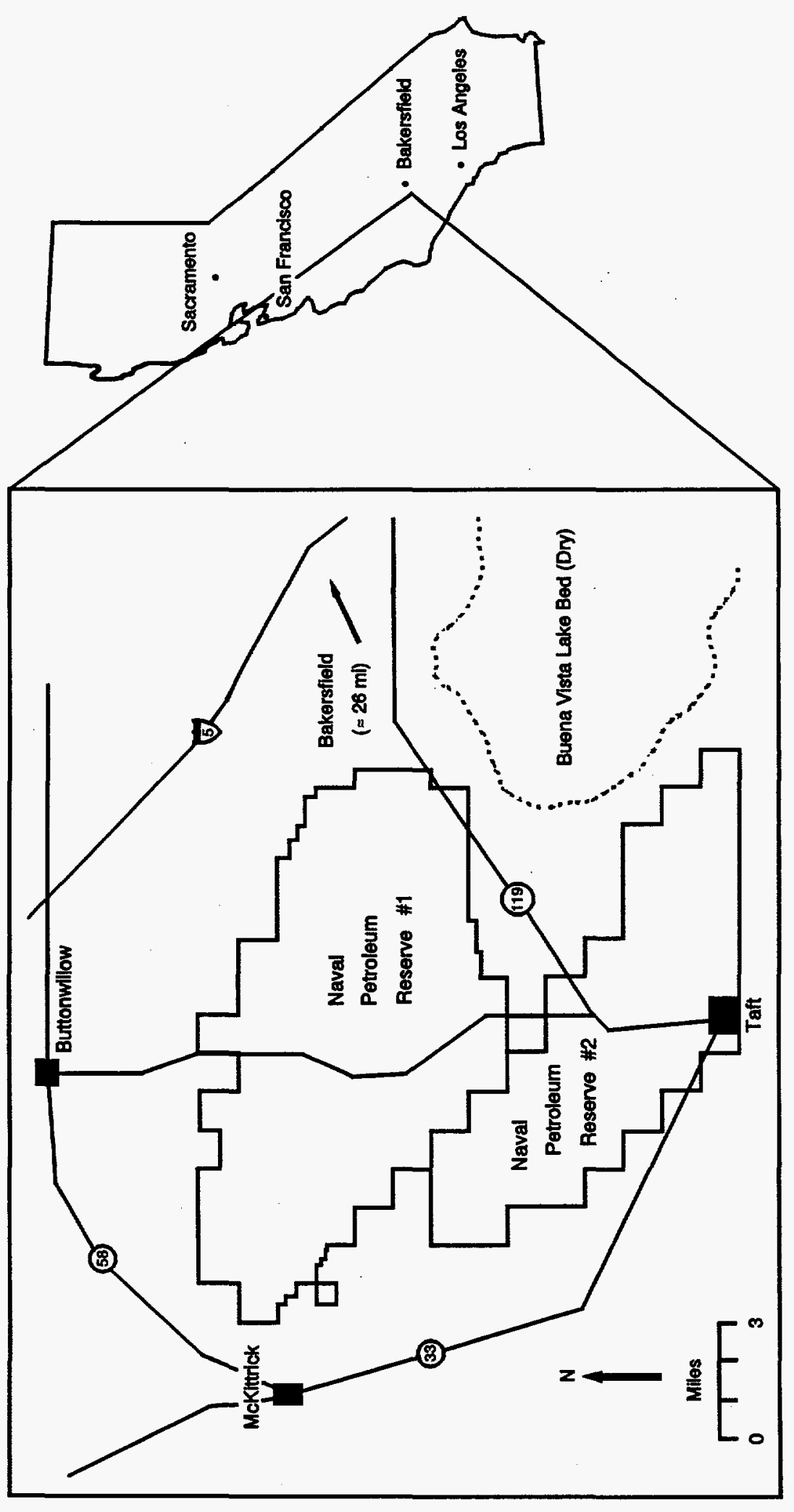

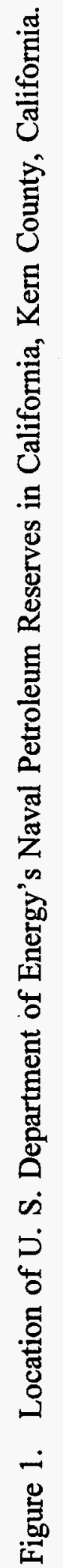




\section{MONITORING}

\section{KIT FOXES}

The kit fox monitoring program continued to provide information about kit fox population trends on NPR-1 and NPR-2. Information from this program is useful in understanding the factors that affect kit fox populations on NPRC.

Fox captures were numerous on both NPR-1 and NPR-2 during winter 1992. On NPR-1, foxes were primarily captured within or near Buena Vista Valley and along the northern and eastern boundaries of NPRC (Figure 2). Kit foxes were captured throughout most of NPR-2 during the 1992 session.

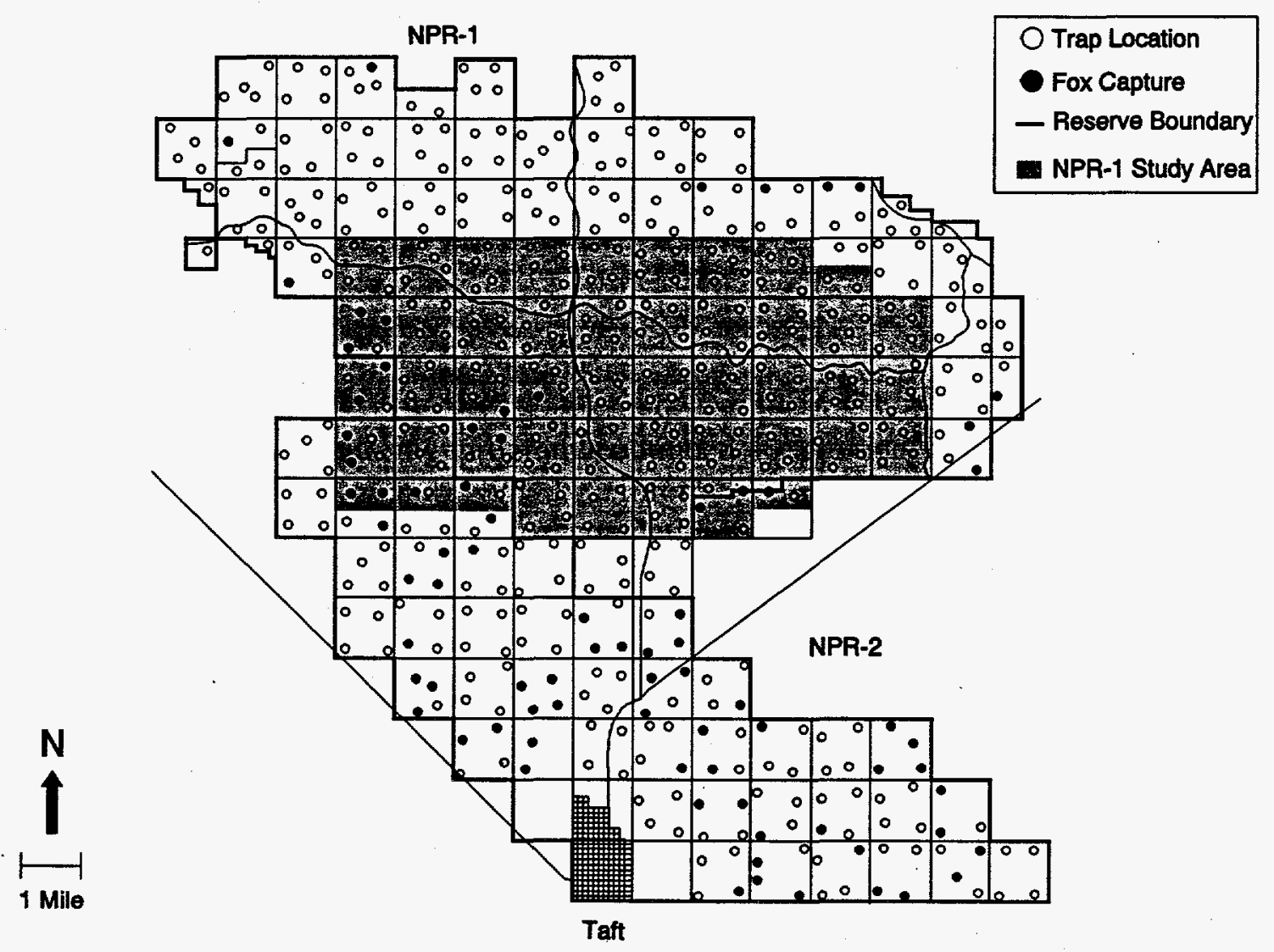

Figure 2. Location of San Joaquin kit fox captures during winter 1992 trapping session, Naval Petroleum Reserves in California, Kern County, California. 
The number of foxes captured and minimum population size were calculated for the NPR-1 study area and NPR-2 and compared with the results of previous trapping sessions (Table 1). Minimum population size was calculated by adding the number of foxes captured during the trapping session to the number of uncaptured foxes that were known to be alive during the session. Because there were no foxes wearing functional radiocollars during the 1992 trapping session, the minimum population size and the number of foxes captured were equivalent for that session. The minimum population sizes in 1992 for the NPR-1 study area (16) and NPR2 (58) were $23 \%$ and $45 \%$ higher, respectively, than the minimum population sizes in 1991 . These represent the first increases in minimum population size in three years on NPR-1 and the first increases in four years on NPR-2.

Table 1. Number of trap-nights, captures, individuals, and estimated minimum population size of San Joaquin kit foxes on the Naval Petroleum Reserves in California, during winter live-trapping sessions, 1981-1992 (NPR-1 study area) and 1983-1992 (NPR-2).

\begin{tabular}{||c|c|c|c|c|c|c|c|c||}
\hline \multirow{2}{*}{ Year } & \multicolumn{2}{|c|}{ Trap-nights } & \multicolumn{2}{c|}{ Captures } & \multicolumn{2}{c|}{ Individuals } & \multicolumn{2}{c|}{$\begin{array}{c}\text { Minimum } \\
\text { Population }\end{array}$} \\
\cline { 2 - 10 } & NPR-1 & NPR-2 & NPR-1 & NPR-2 & NPR-1 & NPR-2 & NPR-1 & NPR-2 \\
\hline \hline 1981 & 711 & & 209 & & 141 & & 165 & \\
\hline 1982 & 710 & & 117 & & 87 & & 131 & \\
\hline 1983 & 712 & 674 & 17 & 88 & 17 & 73 & 75 & 119 \\
\hline 1984 & 711 & 659 & 51 & 133 & 42 & 113 & 61 & 151 \\
\hline 1985 & 708 & 673 & 31 & 106 & 26 & 80 & 44 & 128 \\
\hline 1986 & 712 & 675 & 25 & 124 & 22 & 100 & 33 & 138 \\
\hline 1987 & 712 & 676 & 27 & 99 & 23 & 76 & 36 & 124 \\
\hline 1988 & 712 & 676 & 27 & 125 & 23 & 100 & 37 & 131 \\
\hline 1989 & 712 & 676 & 27 & 77 & 26 & 66 & 42 & 103 \\
\hline 1990 & 712 & 676 & 28 & 91 & 18 & 64 & 21 & 71 \\
\hline 1991 & 712 & 671 & 2 & 28 & 2 & 24 & 13 & 40 \\
\hline 1992 & 712 & 676 & 20 & 63 & 16 & 58 & 16 & 58 \\
\hline \hline
\end{tabular}


Reproduction by San Joaquin kit foxes was assessed on NPR-1 in spring 1993. Twenty-five pupping dens were located during two aerial surveys conducted in May, and two additional dens were located during other field activities. The dens were primarily located in Buena Vista Valley and in the relatively flat north flank area of NPR-1. Of the 25 dens observed, only 21 could be located on the ground. These dens were visited to determine whether they were currently active or inactive. To estimate litter sizes, an evening monitoring session was conducted at one den that appeared active and three pups were observed. Traps were placed at five other dens that appeared active, and three pups were captured at one den while two pups were captured at another.

Although many pupping dens were located, finding currently active dens was difficult because no radiocollared adult foxes were available to monitor. Therefore, relatively few pups were captured or observed. Also, the proportion of female foxes that reproduced could not be estimated due to the lack of radiocollared foxes. However, the number of pupping dens located suggested that reproductive success may have been high in 1993. Also of interest, 14 pupping dens were located on the north flank of NPR-1 where foxes previously were abundant, but where few foxes have been captured in the past two years.

\section{$2.2 \quad$ COYOTES}

Because predation by coyotes is the primary source of mortality for kit foxes on NPRC, scent-station surveys were established in 1984 to provide information that could be used to estimate the relative abundance of carnivores, particularly coyotes (Canis latrans). The program was initially developed to monitor changes in the resident coyote population before, during, and after a coyote control project $(1985$ - 1990). Given the potential impact of coyote predation on the kit fox population and the likelihood of competition between coyotes and kit foxes for food resources, scent-station surveys were continued.

Scent-station surveys were conducted for four consecutive nights in March. Surveys consisted of 25 scent-station lines (15 on NPR-1 and 10 on NPR-2), distributed evenly over both Reserves. Each line consisted of 10 scent-stations placed on alternate sides of secondary roads and spaced at $0.5 \mathrm{~km}$ intervals. Each scent station consisted of a circular $0.9 \mathrm{~m}$ diameter area cleared of all vegetation and debris. A thin layer of fine dust (approximately $2 \mathrm{~mm}$ ) was sifted over the cleared area and a $2.5 \mathrm{~cm}$ plaster-of-Paris disk saturated with fatty-acid scent attractant was placed in the center. Scent-stations were prepared in the afternoon and then examined the following morning for the presence of coyote and other carnivore prints. The presence of at least one print at any given station constituted a positive visit. Visitation indices were then calculated as the proportion of operable stations (those not disturbed by wind, rain, or human-related factors) visited multiplied by 1,000 . 
On NPR-1, the visitation index was 94, suggesting that the relative abundance of coyotes increased after a three year decline (Figure 3). This is the highest spring index obtained for coyotes on NPR-1 since 1986 and is significantly higher $(W=45, P=0.009)$ than the spring 1992 index. On NPR-2 the visitation index was 51 which was slightly greater than the 1992 index of 49. Unlike NPR-1 coyote visits on NPR-2 did not change significantly from 1992 to 1993 (Figure 3).

Scent-station surveys were conducted for three additional nights and were used to evaluate the efficacy of multiple-night surveys and to estimate visitation variability among nights. The coyote visitation indices on NPR-1 during the second and third nights were 122 and 88, respectively. During the fourth night, precipitation rendered all stations inoperable. On NPR-2, coyote visitation for the remaining three nights were 20,61 , and 31 .

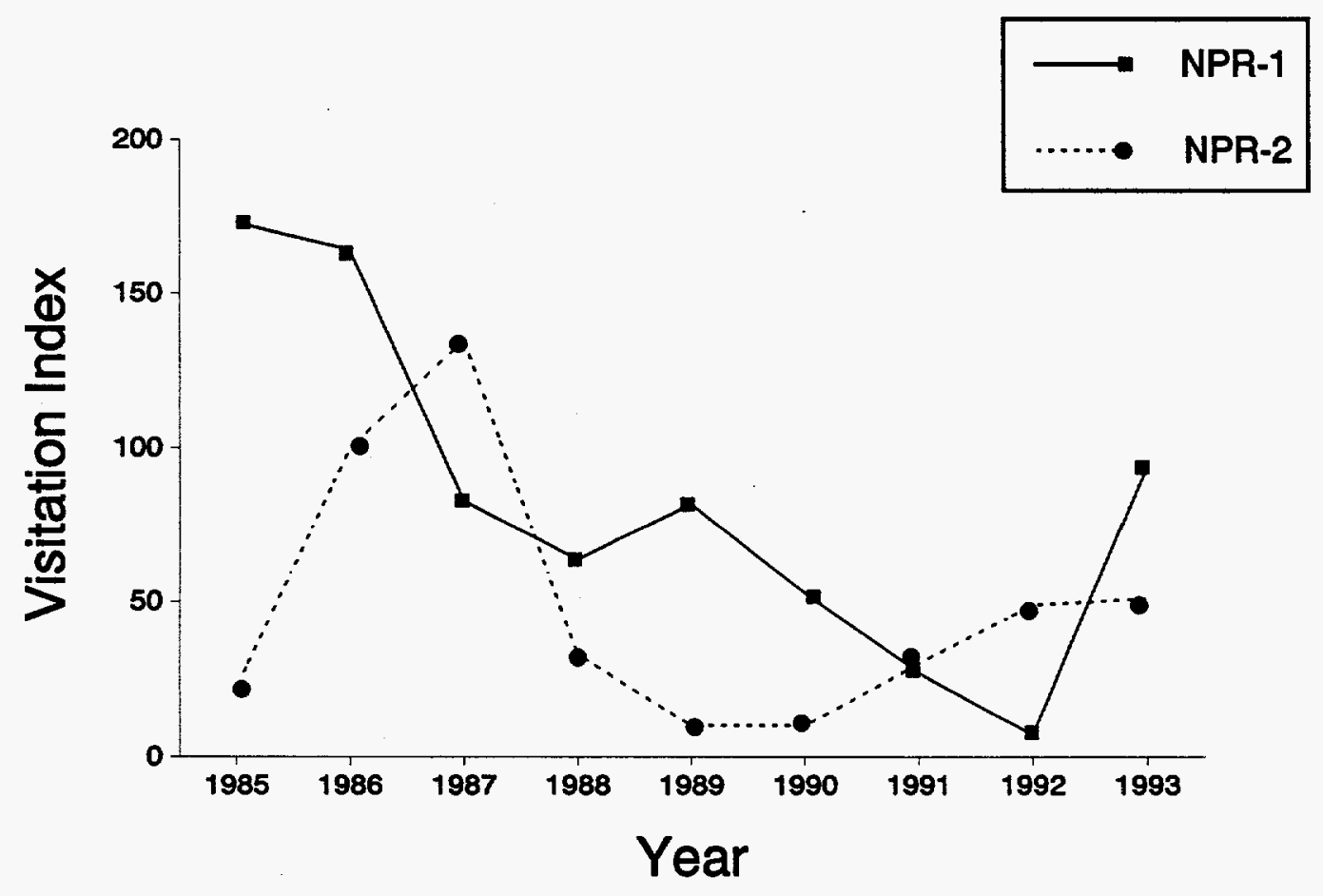

Figure 3. Spring visitation indices for coyotes on the Naval Petroleum Reserves in California, Kern County, California, 1985-1993. 
Black-tailed jackrabbits (Lepus californicus) and desert cottontails (Sylvilagus audubonii) are an important prey item for kit foxes and are monitored annually. Lagomorph populations were monitored in June using line-transect surveys conducted in 78 sections on, and adjacent to, NPR-1 and NPR-2. On NPR-1, 24 of 42 transects occurred in developed sections, while 18 occurred in undeveloped sections. "Developed" sections were those in which more than $15 \%$ of the land was disturbed. On NPR-2, 24 of 36 transects occurred in developed sections, while 12 occurred in undeveloped sections. Transects were one-mile long and consisted of four one-quarter mile legs that formed a square. Observers walked transects between 9:00 am and 4:00 pm and recorded lagomorph species, lagomorph behavior, and the perpendicular distance of observed lagomorphs to the transect line. A Fourier series model was used to calculate density estimates from recorded perpendicular distances. Estimated densities were compared using ztests.

A total of 161 lagomorphs were observed on NPR-1: 104 in developed sections and 57 in undeveloped sections. This is the highest number of lagomorphs observed in summer on NPR-1 since 1988 when 170 were observed. The estimated density of lagomorphs was 171 (SE $=29.8)$ per square mile for all of NPR-1 which was significantly greater $(Z=0.5, P<0.001)$ than the 1992 density estimate of $48(\mathrm{SE}=11.8)$ per square mile (Figure 4). Estimated lagomorph density for developed sections was $215(\mathrm{SE}=45.9)$ per square mile which was not significantly different $(Z=0.46, P=0.085)$ than the estimated density on undeveloped sections $(119, \mathrm{SE}=$ 31.5).

A total of 145 lagomorphs were observed on NPR-2: 112 in developed sections and 33 in undeveloped sections. This is the highest number of lagomorphs observed in summer on NPR-1 since 1986 when 258 were observed. The estimated density of lagomorphs was 177 (SE $=28.0)$ per square mile for all of NPR-2 and was significantly higher $(Z=0.5, P<0.001)$ than the 1992 density estimate of $71(\mathrm{SE}=15.79)$ (Figure 4). Estimated lagomorph density for developed sections was 185 ( $\mathrm{SE}=27.7$ ) per square mile and was not significantly different $(Z$ $=0.18, P=0.631$ ) than the estimated density on undeveloped sections, which was 153 (SE $=$ 60.2). 


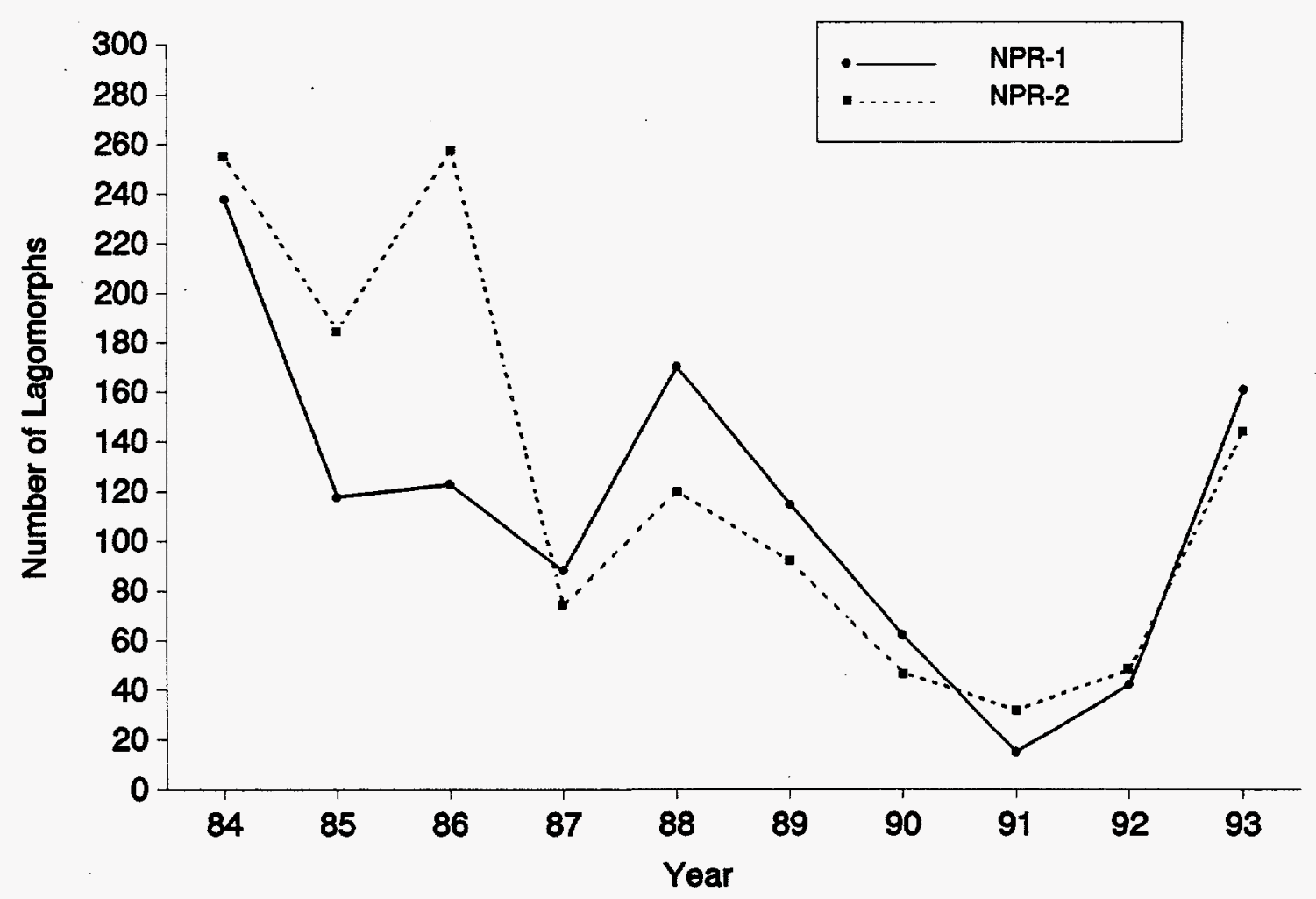

Figure 4. Lagomorphs observed on the Naval Petroleum Reserves in California during summer transects.

A program was initiated in FY93 to monitor abundance and habitat relationships of small mammals on NPR-1. Information obtained from this activity may help explain observed kit fox population trends because small mammals, particularly kangaroo rats, are important prey of kit foxes. Also, understanding small mammal habitat relationships may help explain kit fox distribution patterns on NPR-1. Finally, this monitoring program will provide an annual assessment of the abundance and habitat preferences of two species that are candidates for federal protection, the San Joaquin antelope squirrel (Ammospermophilus nelsoni) and the short-nosed kangaroo rat (Dipodomys nitratoides brevinasus). Therefore, specific objectives of small mammal monitoring are to (1) assess the annual abundance and species composition of small mammals on NPR-1; (2) determine the effects of terrain, aspect, and vegetation characteristics on small mammal abundance and species composition; and (3) determine annual abundance and habitat preferences of San Joaquin antelope squirrels and short-nosed kangaroo rats. 
Small mammal abundance and habitat relationships were assessed by live-trapping at 20 permanent monitoring sites. Five sites were established in each of four "treatments" (SouthFlat, South-Hilly, North-Flat, and North-Hilly) based on position (north or south slope of Elk Hills) and terrain (flat terrain $=0-5^{\circ}$ slope, hilly terrain $=>5^{\circ}$ slope). At each site, 25 trap stations were established at $7.5 \mathrm{~m}$ intervals along an east-west transect. Two Sherman live-traps were placed at each station for a total of 50 traps per site. Traps were pre-baited with a mixture of peanut butter and rolled oats for three nights prior to trapping. Traps were set in late afternoon, and were baited with bird seed and the peanut butter-rolled oat mixture. Traps were checked at sunrise the next morning. Captured small mammals were identified to species, marked ventrally with a non-toxic marking pen, sexed, aged, weighed, and released at the capture site.

To examine the relationship between small mammals and vegetation characteristics, vegetation sampling transects were established at each monitoring site. Transects were $200 \mathrm{~m}$ long and were placed $10 \mathrm{~m}$ south of, and parallel to, each small mammal trapping transect. Percent cover of grasses, forbs, and total vegetation was estimated using an ocular point projection device. Five points were sampled at $5 \mathrm{~m}$ intervals along the transect for a total of 200 points per site. Shrub density was estimated by counting all mature shrubs $(\geq 30-\mathrm{cm}$ tall) in a $200-\mathrm{m} \times 1-\mathrm{m}$ belt along the sampling transects.

Percent total cover varied among treatments at the alpha $=0.1$ level $(F=4.30, \mathrm{df}=$ $1,16, P=0.05$ ), and was highest on North-Flat sites and lowest on South-Flat sites (Table 2). Percent grass cover, percent forb cover, and shrub density did not differ statistically among treatments.

Small mammal trapping was conducted for five consecutive nights from September 27 to October 1, 1993. During this period, 718 individuals of seven species were trapped 1,307 times in 4,993 trap-nights (Table 3). The Heermann's kangaroo rat (Dipodomys heermanni) was the most frequently captured species. Mean capture probability (mean number of individuals captured per 100 trap-nights) for all species combined was highest on North-Hilly sites, but did not differ statistically among treatments, aspect, or terrain $(F=0.50, \mathrm{df}=3,16, P=0.69)$. On individual sites, capture probabilities were weakly correlated with percent total cover $(r=0.40$, $\mathrm{df}=1,18, P=0.08)$, but were not correlated with percent grass cover, percent forb cover, or shrub density.

Physiographic and vegetation characteristics did not appear to significantly affect small mammal abundance, but these characteristics did have a noticeable affect on species composition (Table 3). Number of species captured was highest for the South-Flat treatment $(n=7)$ and lowest for the North-Hilly treatment $(n=4)$. The Heermann's kangaroo rat was the most abundant species on all treatments except South-Flat where short-nosed kangaroo rats were more abundant. Short-nosed kangaroo rats were the second most abundant species on South-Hilly and North-Flat sites, but only one was captured in North-Hilly sites. All San Joaquin pocket mice (Perognathus inornatus neglectus) and the single giant kangaroo rat were captured on South-Flat sites. Southern grasshopper mice (Onychomys torridus) were captured on all treatments except 
North-Hilly. Deer mice (Peromyscus maniculatus) were noticeably more abundant on North-Hilly sites while San Joaquin antelope squirrels were noticeably more abundant on South-Flat sites. A Shannon diversity index was calculated for all treatments (Table 3). The index for the SouthFlat treatment was highest for the South-Hilly treatment followed by the South-Hilly treatment and North-Hilly treatment. The North-Hilly treatment had the lowest diversity index.

Table 2. Vegetation characteristics on small mammal monitoring sites within four physiographic treatments on Naval Petroleum Reserve No. 1, Kern County, California, 1993.

\begin{tabular}{|c|c|c|c|c|c|}
\hline \multirow{2}{*}{ Treatment } & \multicolumn{4}{|c|}{ Mean Percent Cover (SE) } & \multirow{2}{*}{$\begin{array}{c}\text { Mean } \\
\text { Shrub } \\
\text { Density }\end{array}$} \\
\hline & Total & Grass & Forb & Shrub & \\
\hline South-Flat & $\begin{array}{l}60.1 \\
(5.6)\end{array}$ & $\begin{array}{l}51.9 \mathrm{~A}^{\mathrm{a}} \\
(6.0)\end{array}$ & $\begin{array}{c}7.1 \\
(1.6)\end{array}$ & $\begin{array}{c}1.1 \\
(0.5)\end{array}$ & $\begin{array}{l}19.8 \\
(6.8)\end{array}$ \\
\hline South-Hilly & $\begin{array}{l}63.7 \\
(2.5)\end{array}$ & $\begin{array}{l}56.4 \mathrm{~A} \\
(2.8)\end{array}$ & $\begin{array}{c}3.2 \\
(1.5)\end{array}$ & $\begin{array}{c}4.1 \\
(1.0)\end{array}$ & $\begin{array}{c}56.0 \\
(14.5)\end{array}$ \\
\hline North-Flat & $\begin{array}{l}85.2 \\
(3.1)\end{array}$ & $\begin{array}{l}69.8 \mathrm{~B} \\
(3.4)\end{array}$ & $\begin{array}{l}11.6 \\
(3.2)\end{array}$ & $\begin{array}{c}3.8 \\
(1.0)\end{array}$ & $\begin{array}{c}34.0 \\
(15.1)\end{array}$ \\
\hline North-Hilly & $\begin{array}{l}72.8 \\
(4.9)\end{array}$ & $\begin{array}{l}63.4 \mathrm{~B} \\
(4.8)\end{array}$ & $\begin{array}{c}5.4 \\
(0.9)\end{array}$ & $\begin{array}{c}4.0 \\
(1.0)\end{array}$ & $\begin{array}{c}34.6 \\
(14.3)\end{array}$ \\
\hline
\end{tabular}

${ }^{a}$ Means with the same letter within a column are not significantly different $(P>0.05)$.

Although not specifically designed to assess the effects of oil field development on small mammals, levels of development varied among sites providing an opportunity to examine disturbance effects. Mean capture probabilities on eight developed sites (within a section with $>15 \%$ disturbance) and 12 undeveloped sites (within sections with $<15 \%$ disturbance) were 13.6 $(\mathrm{SE}=1.2)$ and $14.9(\mathrm{SE}=1.5)$, respectively, and were not significantly different $(t=0.63$, df $=18, P=0.53)$. Also, site-specific capture probabilities and percent disturbance were not related $(r=-0.17$, df $=1,18, P=0.49)$.

Kangaroo rats are the small mammals most frequently preyed upon by kit foxes. Therefore, kangaroo rat abundance may influence kit fox distribution and abundance. Mean capture probability for all kangaroo rat species combined was highest in the North-Flat 
Table 3. Small mammal captures and diversity indices within four physiographic treatments on Naval Petroleum Reserve No. 1, Kern County, California, 1993.

\begin{tabular}{|c|c|c|c|c|c|c|c|c|c|c|c|}
\hline \multirow[b]{2}{*}{ Treatment } & \multicolumn{8}{|c|}{ Individuals } & \multirow[b]{2}{*}{$\begin{array}{l}\text { Trap- } \\
\text { nights }\end{array}$} & \multirow[b]{2}{*}{$\begin{array}{c}\text { Mean }^{\mathbf{a}} \\
\text { Capture } \\
\text { Probability } \\
\text { (SE) }\end{array}$} & \multirow[b]{2}{*}{$\begin{array}{c}\text { Shannon } \\
\text { Diversity } \\
\text { Index }\end{array}$} \\
\hline & $\begin{array}{l}\text { Short-nosed } \\
\text { Kangaroo Rat }\end{array}$ & $\begin{array}{c}\text { Heermann's } \\
\text { Kangaroo } \\
\text { Rat }\end{array}$ & $\begin{array}{c}\text { Giant } \\
\text { Kangaroo } \\
\text { Rat }\end{array}$ & $\begin{array}{l}\text { San Joaquin } \\
\text { Pocket } \\
\text { Mouse }\end{array}$ & $\begin{array}{l}\text { Deer } \\
\text { Mouse }\end{array}$ & $\begin{array}{l}\text { Southern } \\
\text { Grasshopper } \\
\text { Mouse }\end{array}$ & $\begin{array}{c}\text { San Joaquin } \\
\text { Antelope } \\
\text { Squirrel }\end{array}$ & Total & & & \\
\hline South-Flat & 83 & 19 & 1 & 7 & 2 & 9 & 42 & 163 & 1,250 & $\begin{array}{l}13.0 \\
(3.1)\end{array}$ & 0.58 \\
\hline South-Hilly & 35 & 106 & 0 & 0 & 4 & 4 & 17 & 166 & 1,248 & $\begin{array}{l}13.3 \\
(1.9) \\
\end{array}$ & 0.45 \\
\hline North-Flat & 71 & 99 & 0 & 0 & 6 & 6 & 5 & 187 & 1,250 & $\begin{array}{l}15.0 \\
(1.1) \\
\end{array}$ & 0.44 \\
\hline North-Hilly & 1 & 151 & 0 & 0 & 39 & 0 & 11 & 202 & 1,245 & $\begin{array}{l}16.2 \\
(1.8) \\
\end{array}$ & 0.31 \\
\hline Total & 190 & 375 & 1 & 7 & 51 & 19 & 75 & 718 & 4,993 & $\begin{array}{l}14.4 \\
(1.0) \\
\end{array}$ & - \\
\hline
\end{tabular}

${ }^{a}$ Mean number of individuals captured per 100 trap-nights.

b Shannon Diversity Index $=\frac{n \log n-\sum f_{i} \log f_{i}}{n}$, where $f_{i}$ is number of individuals of the $i^{\text {th }}$ species and $n$ is total number of individuals. 
treatment (Table 4), but did not differ significantly among treatments $(F=1.48, \mathrm{df}=3,16, P=$ $0.26)$. Kangaroo rat capture probabilities on individual monitoring sites were significantly correlated with percent total cover $(r=0.59, \mathrm{df}=1,18, P<0.01)$ and percent grass cover $(r=$ 0.53 , df $=1,18, P=0.02$ ), but did not vary with percent forb cover or shrub density. Thus, vegetation characteristics appeared to have a greater influence on kangaroo rat abundance than physiographic characteristics, although as noted earlier the latter did influence kangaroo rat species composition.

Table 4. Capture probabilities for all kangaroo rats, San Joaquin antelope squirrels, and shortnosed kangaroo rats within four physiographic treatments on Naval Petroleum Reserve No. 1, Kern County, California, 1993.

\begin{tabular}{||l|c|c|c||}
\hline \multirow{2}{*}{ Treatment } & \multicolumn{3}{|c|}{ Mean Capture Probability (SE) } \\
\cline { 2 - 4 } & Kangaroo Rats & $\begin{array}{c}\text { San Joaquin } \\
\text { Antelope Squirrel }\end{array}$ & $\begin{array}{c}\text { Short-nosed } \\
\text { Kangaroo Rat }\end{array}$ \\
\hline \hline South-Flat & $\begin{array}{c}8.2 \\
(3.1)\end{array}$ & $\begin{array}{c}3.4 \mathrm{~A}^{\mathrm{a}} \\
(0.8)\end{array}$ & $\begin{array}{c}6.6 \mathrm{~A} \\
(2.7)\end{array}$ \\
\hline South-Hilly & $\begin{array}{c}11.3 \\
(1.6)\end{array}$ & $\begin{array}{c}1.4 \mathrm{~A} \\
(0.5)\end{array}$ & $\begin{array}{c}2.8 \mathrm{~B} \\
(0.9)\end{array}$ \\
\hline North-Flat & 13.6 & $\begin{array}{c}0.4 \mathrm{~B} \\
(0.3)\end{array}$ & $\begin{array}{c}5.7 \mathrm{~A} \\
(0.8)\end{array}$ \\
\hline North-Hilly & $(1.1)$ & $\begin{array}{c}0.9 \mathrm{~B} \\
(0.4)\end{array}$ & $\begin{array}{c}0.1 \mathrm{~B} \\
(0.1)\end{array}$ \\
\hline
\end{tabular}

${ }^{a}$ Means with the same letter within a column are not significantly different $(P>0.05)$.

Trapping results also provided information on the abundance and habitat relationships of San Joaquin antelope squirrels and short-nosed kangaroo rats, which are federal candidate species. Mean capture probability for San Joaquin antelope squirrels was significantly higher on south $(\bar{x}=2.4, \mathrm{SE}=0.5)$ versus north $(\bar{x}=0.6, \mathrm{SE}=0.2)$ aspect sites $(F=11.44, \mathrm{df}=1,16$, $P<0.01$ ), but did not differ between flat and hilly terrain. Capture probability did differ significantly among treatments $(F=5.94, \mathrm{df}=1,16, P=0.03)$, and was highest on South-Flat sites (Table 4). San Joaquin antelope squirrel capture probabilities were negatively correlated with percent total cover $(r=-0.75$, df $=1,18, P<0.01)$ and percent grass cover $(r=-0.70$, df $=1,18, P<0.01$ ), but did not vary with percent forb cover or shrub density. 
Mean capture probability for short-nosed kangaroo rats was significantly higher in flat (6.2) versus hilly (1.4) terrain $(F=10.04, \mathrm{df}=1,16, P<0.01)$, but did not differ between north and south aspects or among treatments (Table 4). Short-nosed kangaroo rat capture probabilities were not significantly correlated with any vegetation characteristics. Therefore, San Joaquin antelope squirrel distribution and abundance appeared to be primarily influenced by aspect and vegetation characteristics, while short-nosed kangaroo rat distribution and abundance appeared to be primarily influenced by terrain.

\section{$2.5 \quad$ DIET OF KIT FOXES}

Kit fox scats were collected throughout FY93 to assess the prevalence of food items found in scats. Changes in frequency of occurrence of prey items in kit fox scat may reflect the availability of prey species. Fresh scats were collected primarily during live-trapping of kit foxes, scent-station surveys, and during small mammal trapping. Scats were dried and sent to a diagnostic laboratory for analysis.

During FY93, 121 scats were collected. Kangaroo rats occurred in $84.3 \%$ of the scats and were the primary prey species (Table 5). Lagomorphs had the second highest frequency of occurrence (11.6\%). Remains of other mammals found in scats included: San Joaquin antelope squirrels $(1.6 \%)$, pocket mice $(1.6 \%)$, and pocket gopher (Thomomys spp.) $(0.8 \%)$. The frequency of occurrence of kangaroo rats and lagomorphs (the two primary prey species for kit foxes on NPRC) found in scats did not differ significantly $\left(\chi^{2}=0.6, \mathrm{df}=1, P=0.42\right)$ between NPR-1 and NPR-2 (Table 5).

Table 5. Frequency of occurrence (\%) of items found in San Joaquin kit fox scat collected during FY93, Naval Petroleum Reserves in California, Kern County, California.

\begin{tabular}{||r|r|r|r|r|r|r||}
\hline \multirow{2}{*}{ Food Item } & \multicolumn{2}{|c|}{ NPR-1 } & \multicolumn{2}{c|}{ NPR-2 } & \multicolumn{2}{c||}{ Total } \\
\cline { 2 - 8 } & $n$ & $\%$ & $n$ & $\%$ & $n$ & $\%$ \\
\hline \hline Lagomorph & 5 & 9.3 & 10 & 12.8 & 14 & 11.6 \\
\hline Kangaroo Rat & 49 & 90.7 & 62 & 79.5 & 102 & 84.3 \\
\hline $\begin{array}{l}\text { San Joaquin } \\
\text { Antelope Squirrel }\end{array}$ & 1 & 1.8 & 1 & 1.3 & 2 & 1.6 \\
\hline $\begin{array}{l}\text { San Joaquin Pocket } \\
\text { Mouse }\end{array}$ & 1 & 1.8 & 2 & 2.6 & 2 & 1.6 \\
\hline Gopher & 0 & - & 1 & 1.3 & 1 & 0.8 \\
\hline Empty & 0 & - & 2 & 2.6 & 2 & 1.6 \\
\hline Other & 0 & - & 0 & - & 0 & - \\
\hline $\begin{array}{l}\text { Total Scats } \\
\text { Analyzed }\end{array}$ & 54 & & 78 & & 121 & \\
\hline
\end{tabular}


An analysis of 2,646 scats collected between FY83-FY93 indicated that prey selection by kit foxes has changed considerably on NPRC during this period (Figure 5). Between FY83-FY86, primarily lagomorph remains occurred in kit fox scat. Between FY87-FY91, the proportion of kangaroo rats and lagomorph remains found in kit fox scats were about equal. In FY92 and FY93, kangaroo rats remains were found more often than lagomorph remains in kit fox scats.

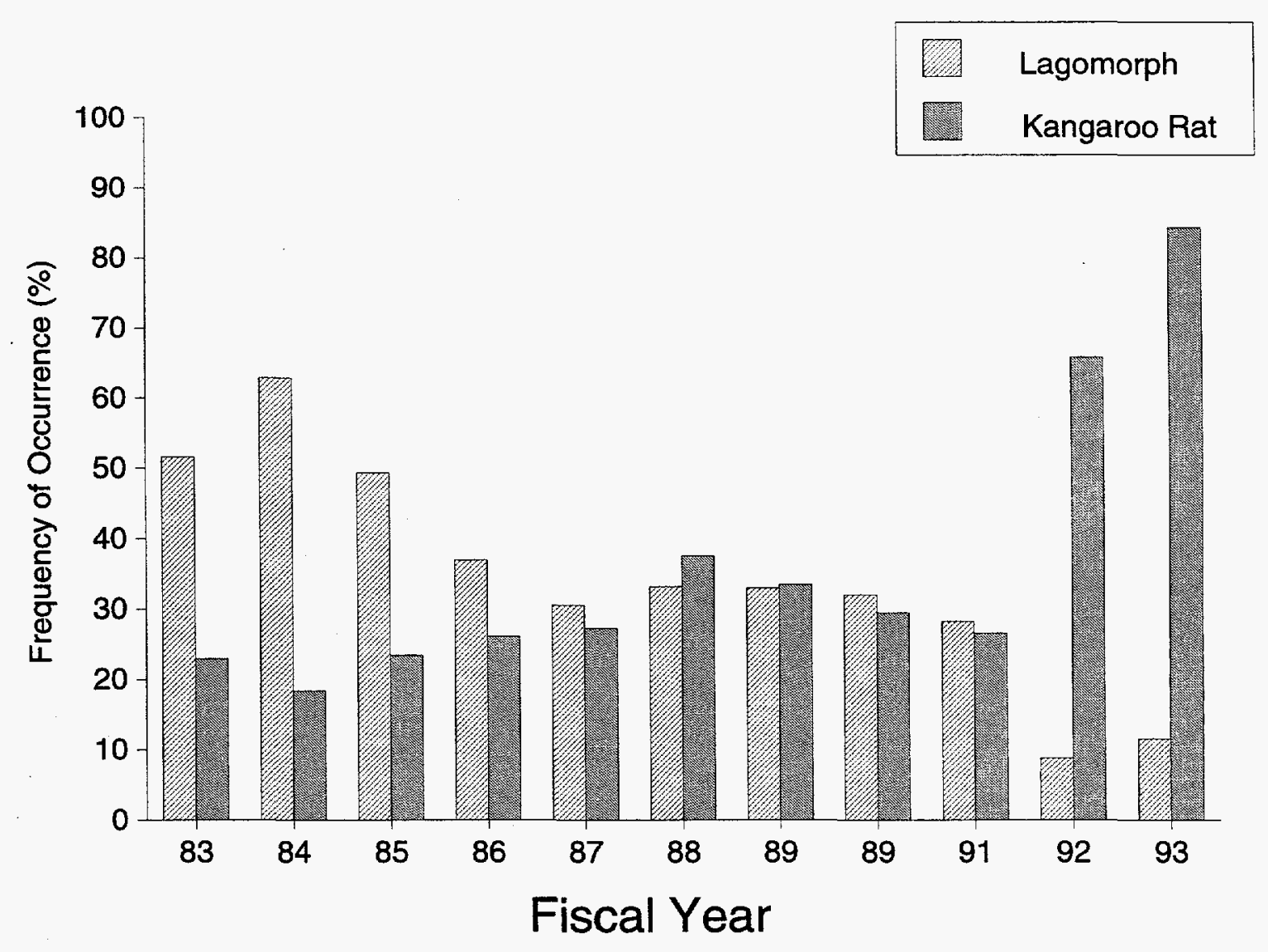

Figure 5. Frequency of occurrence of lagomorph and kangaroo rat remains found in kit fox scat on the Naval Petroleum Reserves in California, FY83 - FY93. 
Beginning in 1981, NPRC sponsored surveys to determine the distribution and population status of the giant kangaroo rat on NPR-1 and NPR-2. At the time, giant kangaroo rats were relatively abundant in the flat or gently sloping terrain near the periphery of the Reserves. Since 1988, however, some evidence has been gathered on NPR-1 suggesting that giant kangaroo rat populations have declined. The cause of the decline is unknown, but consecutive years of below average precipitation between 1988 and 1989 may have been a contributing factor.

To assess the current population status of giant kangaroo rats, a survey of giant kangaroo rat burrow systems (hereafter referred to as precincts), was conducted in 20 sections of NPR-1. In each section, eight 1-mile transects spaced $220 \mathrm{yd}$ apart were walked and the number of giant kangaroo rat precincts observed within $16.4 \mathrm{ft}(5 \mathrm{~m})$ of either side of the transect was recorded (total width $=32.8 \mathrm{ft}$ ). The density of precincts was estimated based on the number of precincts observed in the eight belt transects in each section.

Burrows without fresh scats, tracks, tail marks or fresh sign of digging were considered inactive and were not included in the survey. All precincts were plotted on U. S. Geological Survey topographic maps. Also, observed precincts within colonies, regardless of their distance from the transect, were staked for possible future reference to monitor trends in colony size. Colonies were comprised of clusters of two or more precincts.

Forty-four precincts were observed within the belt transects (Table 6) and the average number of precincts observed within the 20 sections was $2.2(\mathrm{SE}=0.5)$. The estimated density averaged $44.3(\mathrm{SE}=10.7)$ per square mile. Twenty-three giant kangaroo rat colonies were observed in 10 of 20 sections surveyed (Table 6). Average colony size was 4.7 precincts (SE $=$ 0.6).

This survey provided information on the location of active giant kangaroo rat precincts on NPR-1. Such information will be useful to plan future monitoring of giant kangaroo rats, and may provide baseline data for future monitoring activities. 
Table 6. Number of giant kangaroo rat precincts and colonies (cluster of 2 or more precincts) observed in 20 sections of Naval Petroleum Reserve No. 1, Kern County, California, 1993.

\begin{tabular}{|c|c|c|}
\hline $\begin{array}{l}\text { Section Number and } \\
\text { Township }\end{array}$ & $\begin{array}{c}\text { Number of Precincts } \\
\text { Observed }\end{array}$ & $\begin{array}{c}\text { Number of Colonies } \\
\text { Observed }\end{array}$ \\
\hline 1B & 2 & 1 \\
\hline $2 \mathrm{~B}$ & 4 & 2 \\
\hline $3 \mathrm{~B}$ & 4 & 1 \\
\hline $4 \mathrm{~B}$ & 2 & 1 \\
\hline $11 \mathrm{~B}$ & 3 & 5 \\
\hline $12 \mathrm{~B}$ & 0 & 0 \\
\hline $13 \mathrm{~B}$ & 1 & 2 \\
\hline 14B & 4 & 2 \\
\hline $6 \mathrm{G}$ & 1 & 0 \\
\hline $11 \mathrm{G}$ & 4 & 0 \\
\hline $18 \mathrm{G}$ & 8 & 6 \\
\hline $25 \mathrm{R}$ & 2 & 0 \\
\hline $28 \mathrm{R}$ & 0 & 0 \\
\hline $36 \mathrm{R}$ & 0 & 0 \\
\hline $17 \mathrm{~S}$ & 2 & 0 \\
\hline $20 \mathrm{~S}$ & 0 & 0 \\
\hline $21 \mathrm{~S}$ & 0 & 1 \\
\hline $26 \mathrm{~S}$ & 7 & 2 \\
\hline $27 \mathrm{~S}$ & 0 & 0 \\
\hline $31 \mathrm{~S}$ & 0 & 0 \\
\hline
\end{tabular}


Blunt-nosed leopard lizards were monitored using transect surveys conducted on two study plots established on NPRC. One plot was located on the northern side of NPR-1 in Sections 17S and 20S (North Flank), while the other was located in Buena Vista Valley in Sections 4B and 9B (Buena Vista). Each plot was composed of 20 parallel $1 / 4$ mile transects spaced $25 \mathrm{yd}$ apart. The North Flank plot was surveyed 10 times for adults and five times for juveniles, while the Buena Vista plots was surveyed 10 times for adults and 10 times for juveniles. Sex and age information was collected on each leopard lizard observed. In addition, Abundance indices were calculated for each survey period on each study plot by determining the average number of blunt-nosed leopard lizards observed per survey.

Percent ground cover was estimated in June on each of the study plots. Six 200-m transects were randomly placed on each study plot, and five points were sampled at $5 \mathrm{~m}$ intervals for a total of 200 points per transect. The average vegetative cover (grass/forbs/shrubs) on the Buena Vista plot $(\bar{x}=73.8, \mathrm{SE}=4.4)$ was significantly lower $(t=2.92, \mathrm{df}=10, P=0.02)$ than on the North Flank plot $(\bar{x}=87.8, \mathrm{SE}=1.8)$. Average bare-ground points on the Buena Vista plot $(\bar{x}=14.9, \mathrm{SE}=2.5)$ was significantly higher $(t=2.68, \mathrm{df}=10, P=0.023)$ than that on the North Flank plot $(\bar{x}=7.1, \mathrm{SE}=0.8)$.

\subsubsection{Adult Blunt-nosed Leopard Lizards}

Surveys were conducted on the two study plots between June 14 and July 2, 1993 to assess the abundance of adults. The average number of adults observed on the North Flank plot was 2.1 ( $\mathrm{SE}=0.21$ ). Of the 21 blunt-nosed leopard lizards observed throughout this study period, 14 were observed in washes, five were observed on roads, and two were observed in flat areas of patchy to dense vegetation. Of the 21 adults observed $33.3 \%$ were male, $19.1 \%$ were female, and $47.6 \%$ were of unknown sex.

The average number of blunt-nosed leopard lizards on the Buena Vista plot was 4.4 $(\mathrm{SE}=0.28)$. Half of the 44 adults were observed in flat $(n=20)$ to hilly $(n=2)$ areas of sparse to patchy vegetation, 16 were observed in washes, and six were observed on roads. The type of habitat (washes, roads, flats/hillsides) where adults were observed differed significantly between the two plots $\left(\chi^{2}=10.0, \mathrm{df}=2, P=0.007\right)$. The proportion of adult males $(34.1 \%)$, females $(22.7 \%)$, and unknown sex $(43.2 \%)$ on the Buena Vista plot were similar to those on the North Flank plot. 
Surveys to assess the abundance of juveniles were conducted between August 30 and September 20,1993. No juveniles were observed on the North Flank plot during the first five surveys, after which surveys were discontinued. Seven juveniles were observed on the Buena Vista plot $(\bar{x}=0.7, \mathrm{SE}=0.20)$.

\section{8}

\section{HOOVER'S WOOLY-STAR}

Surveys for Hoover's wooly-star on NPR-1 were conducted in 1988, prior to its listing as a threatened species, and again in 1991 to document its location and abundance. The emphasis of efforts in FY93 was on gaining a better understanding of the plant's ecology by (1) characterizing known populations of Hoover's wooly-star, (2) establishing reference populations and initiating long-term monitoring, (3) developing interim management guidelines, (4) evaluating current conservation or management practices, and (5) monitoring reestablishment of Hoover's wooly-star on disturbed areas.

\subsubsection{Habitat Characterization}

The objective of this task was to characterize biotic and abiotic factors associated with populations of Hoover's wooly-star. The parameters measured were percentage of non-vascular plant cover, percentage of vascular plant cover, elevation, slope, aspect, topographic position (crest, upper slope, mid slope, lower slope, bottom), physiographic location (wash, ridge, flat, slope), level of disturbance, and basic soil characteristics. The 265 known locations of Hoover's wooly-star on NPR-1 were grouped into 110 contiguous populations. Soil samples were collected from each population and analyzed.

Average vascular plant cover was $52.8 \%$ ( $\mathrm{SE}=1.5$ ), and ranged from $5 \%$ to $93 \%$. Litter accounted for an average of $10.7 \%(\mathrm{SE}=0.4)$ cover and an average of $26.3 \%(\mathrm{SE}=1.3)$ of the ground was bare. Non-vascular cover, primarily due to lichens and mosses, averaged $10.3 \%(\mathrm{SE}=1.2)$. Total vascular plant cover was comprised of $58.8 \%$ grass, $31.2 \%$ forbs, and $10.0 \%$ shrubs. The number of individual plants of Hoover's wooly-star at each site averaged 2,250 and ranged from 25 to 15,000 .

Populations ranged in elevation from 290 to 1,300 feet and averaged 613 feet. The percentage of Hoover's wooly-star locations found on northerly exposed sites (40\%) and on southerly exposed sites $(43 \%)$ were similar. Seventy-four percent of the sites sampled were located on the lower slopes and bottoms and $26 \%$ were on mid to upper slopes and the crest of hills. Most $(66 \%)$ of the populations were either in low reflief terrain or associated with a wash or drainage. Eighty-four percent of the sites were undisturbed or only slightly disturbed, $13 \%$ were moderately disturbed and $1 \%$ were extremely disturbed. 
Results from soil samples show an average $\mathrm{pH}$ of $7.2(\mathrm{SE}=0.04)$. Electrical conductivity was $0.7 \mathrm{mmhos} / \mathrm{cm}(\mathrm{SE}=0.01$ ), cation exchange capacity was $9.3 \mathrm{meq} / 100 \mathrm{~g}$ (SE $=0.2$ ), organic matter was $1.4 \%(\mathrm{SE}=0.01)$. Ninety-six percent of the sites were found in a loam, sandy/loam, or loam sand soil, and $4 \%$ of the sites were found on silty clay loam or silt loam.

\subsubsection{Hoover's Wooly-star Reference Sites}

Reference sites were established to monitor the status of Hoover's wooly-star on NPR1 over time. Six reference populations of Hoover's wooly-star were selected from the 110 populations. Two were randomly selected from sites located on the on the lower slopes of the North Flank of NPR-1 (sections 20S and 7R), two were randomly selected from sites on the lower slopes of the South Flank (Sections 12B and 17G), and two were randomly selected from sites in the uplands (Sections 33R and 33S). Each reference site is monitored annually during the period of peak vegetative production. Estimates of vascular and non-vascular plant cover, species density (inducing Hoover's wooly-star), and species composition are made annually on three permanent line transects at each site.

Average Hoover's-star cover ranged from 3.7\% $(\mathrm{SE}=1.8)$ at the reference site in Section $7 \mathrm{R}$ to only $1.0 \%(\mathrm{SE}=0.58)$ in Section $17 \mathrm{G}$. The density of Hoover's wooly-star was highest on the two reference sites in the uplands of NPR-1 and lowest at the sites in 17G and 20S. Frequency of occurrence was highest at the reference site in Section $33 \mathrm{~S}$ and lowest in Sections $17 \mathrm{G}$ and 33R. The highest and lowest average vascular plant cover was recorded on the two reference sites located along the northern periphery of NPR-1 in Sections 20S (76.3\%) and 7R (45.0\%), respectively.

Table 7. Average cover, density, and frequency of occurrence of Hoover's wooly-star on six reference sites. Standard error is in parentheses.

\begin{tabular}{||l|c|c|c|c|c|c||}
\hline \multirow{2}{*}{} & \multicolumn{2}{|c|}{ South Flank } & \multicolumn{2}{c|}{ Crest } & \multicolumn{2}{c|}{ North Flank } \\
\cline { 2 - 8 } & $12 \mathrm{~B}$ & $17 \mathrm{G}$ & $33 \mathrm{R}$ & $33 \mathrm{~S}$ & $20 \mathrm{~S}$ & $7 \mathrm{R}$ \\
\hline \hline Cover-Hoover's Wooly-star & 2.0 & 1.0 & 2.0 & 3.3 & 2.7 & 3.7 \\
& $(1.0)$ & $(0.6)$ & $(0.6)$ & $(1.8)$ & $(0.9)$ & $(1.8)$ \\
\hline Density-Hoover's Wooly-star & 56.1 & 23.07 & 78.4 & 86.3 & 22.9 & 48.8 \\
& $(39.4)$ & $(6.09)$ & $(17.0)$ & $(37.4)$ & $(1.4)$ & $(16.1)$ \\
\hline Frequency of Occurrence- & 60.0 & 56.7 & 56.67 & 83.3 & 70.0 & 73.3 \\
Hoover's Wooly-star & $(0.0)$ & $(3.33)$ & $(6.7)$ & $(12.0)$ & $(11.6)$ & $(14.5)$ \\
\hline Total Vascular Plant Cover & 53.0 & 69.7 & 64.3 & 71.0 & 76.3 & 45.0 \\
& $(14.2)$ & $(6.2)$ & $(7.0)$ & $(5.1)$ & $(3.3)$ & $(1.4)$ \\
\hline
\end{tabular}

\subsubsection{Interim Management Guidelines}

A draft topical report entitled, "Distribution, Ecology, and Management of Hoover's Wooly-star (Eriastrum hooveri) on the Naval Petroleum Reserves in California" was prepared in 
April 1993. Current management guidelines described in the report include conducting preactivity surveys prior to ground disturbing activities. If Hoover's wooly-star is found, it is to be avoided when possible. If it cannot be avoided, the surface 2-3 inched of topsoil is to be conserved for redistribution at the project site or an alternate site. The report will be updated as results from other studies become available.

\subsubsection{Experimental Studies on Practices to Conserve Hoover's Wooly-star}

An experimental study was designed and implemented in FY93 to evaluate the effect of topsoil conservation and timing of disturbance on the reestablishment of Hoover's wooly-star. The study included two sites, Site 1 was located in a dense population of Hoover's wooly-star and Site 2 was located in an area void of Hoover's wooly-star, but considered potential habitat. Thirty 6-m x 30-m plots were established at both study sites. Six of the plots at each site were control plots. The remaining 24 plots received one of two treatments, no topsoil added or topsoil added. In April, topsoil from 12 of the plots at Site 1 was removed. The plots were then ripped and disked as were 12 plots at Site 2. Ripping and disking the site was used to simulate a typical ground disturbances. The salvaged topsoil from Site 1 was redistributed onto six plots at Site 1 and six plots at Site 2. These treatments will be used to evaluate the efficacy of redistributing topsoil both in known and potential Hoover's wooly-star habitat, prior to seed set. The same procedures were repeated in July to evaluate the efficacy of redistributing topsoil after seed set.

Prior to disturbance, each of the 60 plots was monitored to obtain baseline data on vascular plant cover, species density, and species composition. Three grasses (red brome, Bromus madritensis; Mediterranean grass, Schismus barbatus; Zorro fescue, Festuca megalura) and four forbs (pygmy weed, Crassula connata; filaree, Erodium cicutarium; pepperweed, Lepidium dictyotum; fiddleneck, Amsinckia intermedia) were the most frequently occurring species on Site 1. On Site 2, three grasses (red brome, Zorro fescue, Mediterranean grass) and two forbs (pygmy weed, filaree) were the most frequently occurring species. In the future, the effects of the different treatments on the density of Hoover's wooly-star will be evaluated.

\subsubsection{Monitor Reestablishment of Hoover's Wooly-star Following Disturbance}

In fall 1990, two large-scale projects occurred in known Hoover's wooly-star habitat. One project involved the replacement of a pipeline by Southern California Gas Company, and impacted approximately 18 acres of Hoover's wooly-star habitat. The second was the construction of a source water well, which impacted approximately 0.5 acres of Hoover's woolystar habitat. Since 1990 , both project sites have been monitored annually to determine if Hoover's wooly-star has become reestablished after disturbance. 


\subsubsection{Monitor Reestablishment of Hoover's Wooly-star on Section 14B Source Water Well}

In July 1990, construction began on well 282WS-14B, before an Endangered Species Preactivity Survey could be conducted. About half of the area proposed for the new well pad ( 0.5 acres) was scraped and the surface 3-4 inches of topsoil was stockpiled. A subsequent preactivity survey revealed several small populations of Hoover's wooly-star in the adjacent undisturbed portion of the new well pad site. To avoid further disturbance to Hoover's woolystar, the proposed well was relocated.

The disturbed area was established as a study site with the objectives of evaluating the effect of disturbance on the reestablishment of Hoover's wooly-star and evaluating the effect of standard reclamation techniques on Hoover's wooly-star reestablishment. As part of the study design, the stockpiled topsoil was returned to the site. One-half of the site was seeded, with a mix of shrubs (Atriplex polycarpa, Eriogonum fasciculatum, Isomeris arborea), grass (Festuca megalura), and forbs (Trifolium hirtum, Lupinus densiflorus, Phacelia tanacetifolia). The other half was not seeded. Three permanent sampling transects were established in the seeded and unseeded disturbed areas as well as in an adjacent undisturbed habitat.

In general, the density of Hoover's wooly-star has increased since the disturbance (Table 8). The disturbed treatment with no seeding has almost as high a density of Hoover's wooly-star as the undisturbed control. There are less than one-half as many individuals of Hoover's wooly-star on the seeded treatment as on the unseeded and control sites. These results indicate that Hoover's wooly-star readily reestablishes on newly disturbed areas within three years, but that reestablishment may be hindered if competing species are intentionally seeded.

Table 8. Average density $\left(\right.$ no. $\left./ \mathrm{m}^{2}\right)$ of Hoover's wooly-star on study plots near well 282WS14B. Standard errors are in parentheses.

\begin{tabular}{||c|c|c|c||}
\hline Treatment & 1991 & 1992 & 1993 \\
\hline \hline Disturbed Seeded & $\begin{array}{c}0.4 \\
(0.2)\end{array}$ & $\begin{array}{c}2.3 \\
(1.3)\end{array}$ & $\begin{array}{c}4.4 \\
(2.0)\end{array}$ \\
\hline Disturbed/Not Seeded & $\begin{array}{c}7.7 \\
\end{array}$ & $\begin{array}{c}4.0 \\
(0.9)\end{array}$ & $\begin{array}{c}11.6 \\
(7.0)\end{array}$ \\
\hline Undisturbed Control & $\begin{array}{c}0.8 \\
\end{array}$ & $\begin{array}{c}1.9 \\
(0.3)\end{array}$ & $\begin{array}{c}12.4 \\
(0.8)\end{array}$ \\
\hline
\end{tabular}




\subsubsection{Monitor Reestablishment of Hoover's Wooly-star on Southern California Gas Company Pipeline}

In 1990, Southern California Gas Company completed the replacement of one pipeline and the removal of another along the southern boundary of NPR-1. Prior to construction in Hoover's wooly-star habitat, the surface 2-3 inches of topsoil were stockpiled. Following construction activities, the topsoil was replaced and all disturbed areas were seeded with a mix of shrub, grass, and forb species. Ten paired study plots were established along the pipeline corridor where the Hoover's wooly-star topsoil had been replaced. For each pair, one study plot was located outside the pipeline corridor in undisturbed Hoover's wooly-star habitat, and the other was located within the reclaimed pipeline corridor. The plots have been monitored for the last three years.

The density of Hoover's wooly-star has increased since the disturbance (Table 9). After just three years density estimates are approaching those recorded on the adjacent undisturbed control plots. These results also indicate that Hoover's wooly-star can become reestablished on disturbed sites within three years.

Table 9. Average density (no. $/ \mathrm{m}^{2}$ ) of Hoover's wooly-star on study plots located along Southern California Gas Company Pipeline. Standard errors are in parentheses.

\begin{tabular}{||c|c|c|c||}
\hline Treatment & 1991 & 1992 & 1993 \\
\hline \hline Disturbed Seeded & $\begin{array}{c}0.1 \\
(0.03)\end{array}$ & $\begin{array}{c}3.1 \\
(1.8)\end{array}$ & $\begin{array}{c}9.84 \\
(4.5)\end{array}$ \\
\hline Undisturbed Control & $\begin{array}{c}2.1 \\
(0.7)\end{array}$ & $\begin{array}{c}9.7 \\
(2.8)\end{array}$ & $\begin{array}{c}11.36 \\
(4.8)\end{array}$ \\
\hline
\end{tabular}

\subsection{METEOROLOGICAL DATA FOR NPR-1}

Meteorological data have been colllected on NPR-1 since March 1981. This information provides a valuable database for endangered species monitoring and habitat conservation studies. Eight stations located throughout NPR-1 were equipped with precipitation gauges and a maximum/minimum thermometer. Three additional stations were each equipped with a hygrothermograph to record daily temperature and relative humidity, and a precipitation gauge to record rainfall. 
Annual precipitation is reported by water year (WY), which begins July 1 and ends June 30 of the following year. Since 1981, average precipitation on NPR-1 has ranged between 2.0 inches in WY88 to 7.6 inches in WY92 (Figure 6).

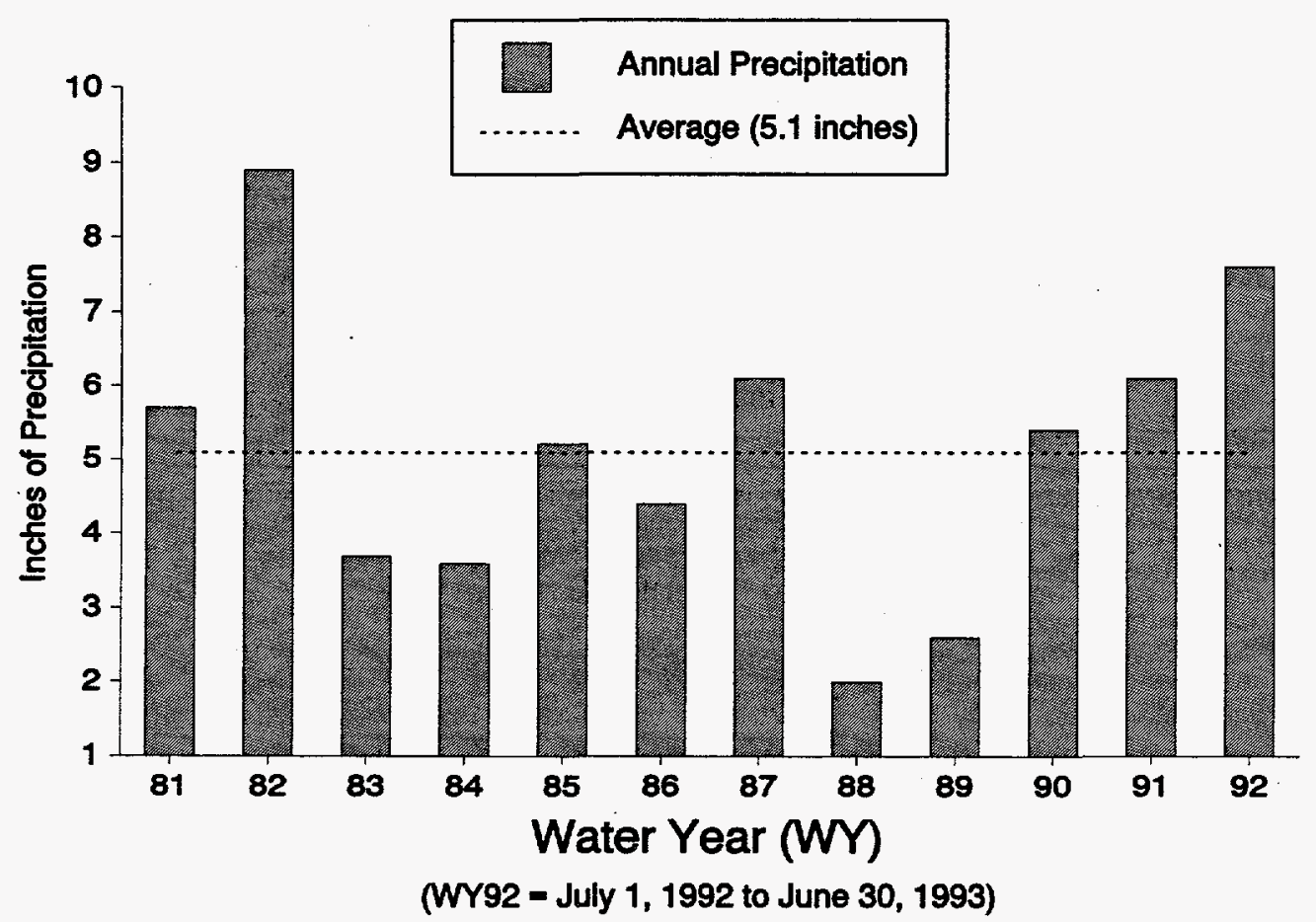

Figure 6. Average annual precipitation for water years 1981 to 1992, Naval Petroleum Reserve No. 1, Kern County, California.

The highest average maximum monthly temperature in WY 92 was $108^{\circ} \mathrm{F}$ recorded in June 1992 (Table 10). The lowest average minimum monthly temperature was $25^{\circ} \mathrm{F}$ recorded in December 1992. 
Table 10. Average maximum and minimum temperatures $\left({ }^{\circ} \mathrm{F}\right)$ recorded during WY92 at eight stations located on Naval Petroleum Reserve No. 1, Kern County, California.

\begin{tabular}{|l|l|l|l|l|l|l|l|l|l|l|l|l|}
\hline & July & Aug & Sept & Oct & Nov & Dec & Jan & Feb & Mar & Apr & May & June \\
\hline $\begin{array}{l}\text { Average Maximum } \\
\left.\text { Temperature ( }{ }^{\circ} \mathrm{F}\right)\end{array}$ & 103 & 107 & 105.7 & 96.3 & 77.3 & 71.5 & 67 & 75 & 82.1 & 87.3 & 102 & 108 \\
\hline $\begin{array}{l}\text { Average Minimum } \\
\left.\text { Temperature ( }{ }^{\circ} \mathrm{F}\right)\end{array}$ & 58 & 56 & 54.3 & 48.8 & 35.7 & 25 & 27 & 37 & 39.5 & 39 & 42 & 48.9 \\
\hline
\end{tabular}

\subsubsection{Relative Humidity}

Weather data collected at three stations included daily maximum and minimum temperatures and daily maximum and minimum relative humidity. The highest average maximum daily temperature was $98.2^{\circ} \mathrm{F}$ recorded in August 1992 . The lowest average minimum daily temperature was $37.4^{\circ} \mathrm{F}$ recorded in December 1992 . The highest average maximum daily relative humidity was $79.6 \%$ recorded in January 1992 . The lowest average minimum daily relative humidity was $22.9 \%$ recorded in June 1992 (Table 11).

Table 11. Average daily maximum and minimum temperatures $\left({ }^{\circ} \mathrm{F}\right)$ and average daily maximum and minimum relative humidity (\%) recorded during water year 1992 at three stations on Naval Petroleum Reserve No. 1, Kern County, California.

\begin{tabular}{|l|c|c|c|c|c|c|c|c|c|c|c|c|}
\hline & July & Aug & Sept & Oct & Nov & Dec & Jan & Feb & Mar & Apr & May & June \\
\hline \hline $\begin{array}{l}\text { Average Daily Maximum } \\
\text { Temperature ('F) }\end{array}$ & 92.5 & 98.2 & 82.9 & 79.9 & 68.0 & 49.8 & 53.0 & 59.1 & 67.8 & 72.8 & 85.1 & 89.8 \\
\hline $\begin{array}{l}\text { Average Daily Minimum } \\
\text { Temperature ('F) }\end{array}$ & 71.8 & 76.6 & 58.7 & 62.3 & 49.3 & 37.4 & 41.6 & 44.8 & 51.3 & 51.2 & 60.0 & 66.9 \\
\hline $\begin{array}{l}\text { Average Daily Maximum } \\
\text { Relative Humidity (\%) }\end{array}$ & 59.8 & 46.8 & 55.7 & 69.9 & 67.9 & 77.4 & 79.6 & 74.5 & 78.1 & 69.5 & 64.5 & 47.6 \\
\hline $\begin{array}{l}\text { Average Daily Minimum } \\
\text { Relative Humidity (\%) }\end{array}$ & 34.4 & 27.9 & 31.8 & 41.1 & 34.3 & 51.7 & 52.7 & 42.6 & 42.9 & 31.6 & 28.1 & 22.9 \\
\hline
\end{tabular}




\subsubsection{Soil Temperatures}

Soil temperatures reported in Table 12 are averages from three weather station locations. Temperatures were taken monthly at three soil depths in two habitat types between January and November 1992. In the open grass area, soil temperatures at all depths (1-in, 6-in, and 15-in) were highest during July and lowest during January.

Table 12. Soil temperatures $\left({ }^{\circ} \mathrm{F}\right)$ from January 1992 to November 1992 at three depths for open grassland and shrub understory.

\begin{tabular}{||c|c|c|c|c|c|c||}
\hline \multirow{2}{*}{ Month } & \multicolumn{3}{|c|}{ Open Grass } & \multicolumn{3}{c||}{ Shrub Understory } \\
\cline { 2 - 7 } & \multicolumn{1}{|c|}{$1^{\prime \prime}$} & $6^{\prime \prime}$ & $15^{\prime \prime}$ & $11^{\prime \prime}$ & $6^{\prime \prime}$ & $15^{\prime \prime}$ \\
\hline \hline January & 57.7 & 48.0 & 45.7 & 45.0 & 46.7 & 46.0 \\
\hline February & 59.3 & 52.0 & 51.0 & 50.7 & 49.7 & 51.0 \\
\hline March & 70.3 & 61.7 & 58.3 & 58.0 & 55.7 & 56.0 \\
\hline April & 98.0 & 81.0 & 78.0 & 72.0 & 70.0 & 70.0 \\
\hline May & 110.0 & 98.0 & 91.0 & 93.0 & 87.0 & 85.0 \\
\hline June & 105.3 & 89.3 & 89.3 & 85.3 & 83.3 & 84.7 \\
\hline July & 110.0 & 103.0 & 95.3 & 94.7 & 90.0 & 90.0 \\
\hline August & 101.0 & 87.0 & 89.0 & 84.0 & 83.0 & 85.0 \\
\hline September & 81.7 & 81.3 & 85.0 & 76.7 & 78.3 & 81.3 \\
\hline October & 75.3 & 65.3 & 67.3 & 62.0 & 62.0 & 66.0 \\
\hline November & 58.3 & 51.3 & 53.7 & 50.3 & 50.0 & 53.7 \\
\hline \hline
\end{tabular}

Soil temperatures recorded in the shrub understory were usually cooler than corresponding readings in the open grass areas for all three depths. The maximum temperature at the surface (1-in) in the shrub understory occurred in July. The maximum temperature recorded was approximately 15 degrees cooler than the maximum temperature recorded at the surface in the open grass area. The lowest soil temperature at the 1-in depth was recorded in January and was about 10 degrees cooler than in the open grass area. At 6-in and 15-in depths, the highest soil temperature was recorded in July and the lowest was in January. 
In 1990, Hoover's wooly-star, Kern Mallow (Eremalche kernensis), San Joaquin wooly-threads (Lembertia congdonii), and California jewelflower (Caulanthus californicus) were federally-listed as either threatened or endangered. In spring 1988, a survey of NPR-1 was conducted to determine their occurrence. Of the four species, only Hoover's wooly-star was found. It was concluded that Kern mallow and San Joaquin wooly-threads could potentially be found on NPR-1, but habitat for California jewelflower did not occur on NPR-1 and its occurrence was unlikely.

A second survey for these species was conducted in 1991, which was the first growing season with above or near normal spring precipitation since the species had been listed. The distribution of Hoover's wooly-star was further documented, but San Joaquin wooly-threads and Kern mallow were not found. After three years of above normal precipitation at NPRC, a third survey was conducted in FY93 to obtain more conclusive information on the presence of the listed and candidate species that could potentially occur on NPR-1.

The objective of the FY93 survey was to document the presence of special status plant species on NPRC. A special status species is one that is currently protected or is under consideration for protection by the federal government. The three objectives of this survey were to:

- Review existing literature and determine which federally-listed or candidate plant species are most likely to occur on NPRC.

- Conduct a floristic survey for those special status plant species and determine if and where they occur on NPRC.

- Obtain sufficient information to prepare a report documenting the occurrence, distribution, and abundance of special status plant species on NPRC.

A total of 14 special status plant species that occur, or potentially occur, on NPRC were identified during the literature search. Two of the 14 species, Lost Hills saltbush (Atriplex vallicola) and Hoover's wooly-star, were dropped from the survey list. Lost Hills saltbush is conspecific with Valley saltbush $(A$. cornata), a common species, and the distribution of Hoover's wooly-star is already well known. Six species were listed as species to watch for, but were unlikely to occur on NPRC. The remaining six species which had a medium or high likelihood of occurrence on NPRC were the focus of this survey (Table 13). 
Table 13. List of special status plants species potentially occurring on the Naval Petroleum Reserves in California that are federal endangered species (E) or candidates for protection (C2).

\begin{tabular}{|c|c|c|c|c|c|c|}
\hline \multirow{2}{*}{ Species } & \multirow{2}{*}{ Common Name } & \multirow{2}{*}{ Status* } & \multirow{2}{*}{ Habitat Requirements } & \multicolumn{3}{|c|}{$\begin{array}{l}\text { Potential for } \\
\text { Occurrence }\end{array}$} \\
\hline & & & & High & Med. & Low \\
\hline Atriplex tularensis & Bakersfield Saltbush & $\mathrm{C} 2$ & Chenopod Scrub & & & $\mathbf{X}$ \\
\hline Atriplex cordulata & Heartscale & $\mathrm{C} 2$ & Chenopod Scrub & & $\mathbf{x}$ & \\
\hline Amsinckia furcata & Forked Fiddleneck & $\mathrm{C} 2$ & $\begin{array}{l}\text { Valley \& Foothill } \\
\text { Grassland }\end{array}$ & & & $\mathbf{x}$ \\
\hline Calachortus striatus & Alkali Mariposa Lily & $\mathrm{C} 2$ & $\begin{array}{l}\text { Chenopod Scrub, } \\
\text { Alkaline Meadows }\end{array}$ & & $\mathbf{x}$ & \\
\hline $\begin{array}{l}\text { Caulanthus } \\
\text { californicus }\end{array}$ & California Jewelflower & $\mathbf{E}$ & $\begin{array}{l}\text { Chenopod Scrub, } \\
\text { Valley and Foothill } \\
\text { Grassland }\end{array}$ & & & $\mathrm{X}$ \\
\hline Cirsium crassicaule & Slough Thistle & $\mathrm{C} 2$ & Marshes, Swamps & & & $\mathrm{x}$ \\
\hline $\begin{array}{l}\text { Cordylanthus mollis } \\
\text { hispidus }\end{array}$ & Hispid Bird's-beak & $\mathrm{C} 2$ & Alkaline Meadows & & & $\mathbf{x}$ \\
\hline $\begin{array}{l}\text { Delphinium } \\
\text { recurvatum }\end{array}$ & Recurved Larkspur & $\mathrm{C} 2$ & $\begin{array}{l}\text { Chenopod Scrub, } \\
\text { Valley \& Foothill } \\
\text { Grassland }\end{array}$ & & $\mathbf{X}$ & \\
\hline Eremalche kernensis & Kern Mallow & $\mathbf{E}$ & $\begin{array}{l}\text { Chenopod Scrub, } \\
\text { Valley \& Foothill } \\
\text { Grassland }\end{array}$ & & $\mathbf{X}$ & \\
\hline Hollisteria lanata & Hollisteria & $\mathrm{C} 2$ & $\begin{array}{l}\text { Chenopod Scrub, } \\
\text { Valley \& Foothill } \\
\text { Grassland }\end{array}$ & $\mathbf{x}$ & & \\
\hline Layia leucopappa & Comanche Point Layia & $\mathrm{C} 2$ & $\begin{array}{l}\text { Chenopod Scrub, } \\
\text { Valley \& Foothill } \\
\text { Grassland }\end{array}$ & & & $\mathrm{x}$ \\
\hline Lembertia congdonii & $\begin{array}{l}\text { San Joaquin Wooly- } \\
\text { threads }\end{array}$ & $\mathrm{E}$ & $\begin{array}{l}\text { Chenopod Scrub, } \\
\text { V\&F Grassland }\end{array}$ & & $\mathbf{x}$ & \\
\hline
\end{tabular}


The survey was conducted in areas of NPRC with the greatest potential for the occurrence of the six plant species that were the focus of the survey. The search areas were primarily around the perimeter of NPRC, including the north and east flanks (along the California Aqueduct), and in Buena Vista and Midway Valleys.

Approximately 7,000 acres were surveyed between April and June 1993. Previously unrecorded populations of Hollisteria (Hollisteria lanata) were located in Sections 7R, 30R, and 12C. Suspected populations of Kern mallow were tentatively identified in Sections 9G, 12G, and $18 \mathrm{H}$. Due to collecting restrictions, positive identifications were not made. No other special status plant species were observed during surveys. Although not an objective of this survey, several new populations of Hoover's wooly-star were also recorded. A draft topical report entitled, "Occurrence and Distribution of Special Status Plant Species on Naval Petroleum Reserves in California" was completed. 


\section{PREACTIVITY SURVEYS AND CULTURAL RESOURCE SUPPORT}

\subsection{ENDANGERED SPECIES AND CULTURAL RESOURCE PREACTIVITY SURVEYS}

During FY93, 455 preactivity surveys were conducted on 836 acres on or adjacent to NPRC. Of this, 205 surveys were classified as emergencies (projects requiring a preactivity surveys within three working days). Most emergency surveys were conducted for cleanups, pipelines, and other miscellaneous construction projects. Compared with FY92, 223 fewer surveys were conducted in FY93 (a 33\% decrease). There was a 19\% decrease in the number of acres surveyed from 1,029 in FY92 to 836 in FY93.

A total of nine known kit fox dens and 87 potential kit fox dens were identified during surveys in FY93. A known kit fox den is defined as any existing natural den for which there is conclusive evidence, or strong circumstantial evidence, that the den is in use or has been used by a San Joaquin kit fox. A potential kit fox den is defined as any natural den within the species' range that could provide cover for a fox, but exhibits no evidence of kit fox origin or use. A total of six blunt-nosed leopard lizards were observed and 13 washes representing potential blunt-nosed leopard lizard habitat were identified. Two giant kangaroo rat burrows and 88 populations of Hoover's wooly-star also were identified (Table 14).

Recommendations to prevent potential impacts to endangered species, their habitats, or revegetated areas were made on a total of $74(16 \%)$ projects in FY93. Oil spills, pipelines, and other miscellaneous construction or maintenance projects were most often affected. Alterations usually included the establishment of avoidance zones around dens and burrows, restriction of vehicle travel in wash areas, and establishment of avoidance zones around populations of Hoover's wooly-star. Some pipelines were slightly rerouted, and some oil spill cleanups were accomplished with hand tools to avoid direct impact to endangered species habitat. During FY93, no potential kit fox dens were excavated at project sites. One new well site was moved, however, to avoid a population of Hoover's wooly-star observed in the project area.

Direct impacts to endangered species and their habitats were avoided on all projects, except the disking of the NPR-1 firebreak. During firebreak maintenance, portions of six populations of Hoover's wooly-star could not be avoided. Disturbance of these populations were permitted in a Biological Opinion rendered by FWS for this activity in June 1992.

Follow-up surveys were conducted on 56 of the 74 projects where evidence of endangered species, their habitats, or revegetated areas were encountered during the initial preactivity survey. Eighteen projects were either canceled or postponed until Fiscal Year 1994 and were not subjected to a follow-up survey. Follow-up surveys were conducted within 90 days of the initial survey, or when the project was completed. Recommendations were followed on all 56 projects completed in FY93 for which recommendations were made. These results were reported to DOE and the Unit Operator in a monthly summary letter. 
Table 14. Summary of endangered species preactivity surveys conducted during FY93 on the Naval Petroleum Reserves in California.

\begin{tabular}{|c|c|c|c|c|c|c|c|c|c|}
\hline & \multicolumn{8}{|c|}{ Project Type } & \multirow{2}{*}{$\begin{array}{l}\text { FY93 } \\
\text { Totals }\end{array}$} \\
\hline & Cleanups & $\begin{array}{l}\text { Corrosion } \\
\text { Protection } \\
\end{array}$ & Pipelines & Powerlines & $\begin{array}{l}\text { New } \\
\text { Well Pad } \\
\end{array}$ & $\begin{array}{l}\text { Well Pad } \\
\text { Regrade } \\
\end{array}$ & Firebreak & Other & \\
\hline Surveys Conducted & 180 & 20 & 80 & 35 & 23 & 4 & 1 & 112 & 455 \\
\hline Acres Surveyed & 86 & 21 & 110 & 74 & 202 & 5 & 178 & 160 & 836 \\
\hline $\begin{array}{l}\text { Known Kit Fox } \\
\text { Dens }\end{array}$ & 2 & 0 & 0 & 0 & 3 & 0 & 3 & 1 & 9 \\
\hline $\begin{array}{l}\text { Potential Kit Fox } \\
\text { Dens }\end{array}$ & 21 & 0 & 12 & 17 & 24 & 0 & 4 & 9 & 87 \\
\hline $\begin{array}{l}\begin{array}{l}\text { Giant Kangaroo Rat } \\
\text { Burrows }\end{array} \\
\end{array}$ & 0 & 0 & 0 & 0 & 0 & 0 & 0 & 2 & 2 \\
\hline $\begin{array}{l}\text { Blunt-nosed } \\
\text { Leopard Lizards } \\
\text { Observed }\end{array}$ & 0 & 0 & 0 & 0 & 0 & 0 & 6 & 0 & 6 \\
\hline Washes Observed & 9 & 1 & 1 & 1 & 0 & 0 & 0 & 1 & 13 \\
\hline $\begin{array}{l}\text { Hoover's Wooly- } \\
\text { star Populations }\end{array}$ & 20 & 0 & 15 & 15 & 6 & 0 & 0 & 32 & 88 \\
\hline
\end{tabular}

\subsection{CULTURAL RESOURCES SUPPORT}

\subsubsection{Cultural Resource Support}

Prehistoric and historic cultural resources found on NPRC are protected under the National Historic Preservation Act of 1966 (as amended) and the Archaeological Resources Protection Act of 1979 (Public Law 96-95). Section 106 of the National Historic Preservation Act requires federal agencies to take into account the effects of agency actions on historic properties. Section 110 requires all federal agencies to carry out programs in accordance with national historic preservation policy. The Archaeological Resources Protection Act secures the protection of archaeological resources and sites for the present and future benefit of the American people.

Two cultural resource surveys and accompanying reports were completed for one third-party project (167-acre survey) and one DOE project (109-acre survey) (Table 15). Three prehistoric lithic scatters (two with shell) and one isolated flake were recorded. No sites were eligible to the National Register of Historic Places. The California State Historic Preservation Officer (SHPO) determined that the city of Taft site did not meet the National Historic Preservation Act criteria for eligibility. Comments from SHPO concerning the $5 \mathrm{M} / 6 \mathrm{M}$ powerline project have not been received. 
Table 15. Summary of cultural resource assessments for third-party projects completed during FY93.

\begin{tabular}{||c|l|l|l|l|l|l||}
\hline $\begin{array}{c}\text { Survey } \\
\text { Date }\end{array}$ & \multicolumn{1}{|c|}{$\begin{array}{c}\text { Project } \\
\text { Description }\end{array}$} & Section & Acres & No. Arch. Sites & No. Isolates & \multicolumn{1}{|c||}{ SHPO' Review } \\
\hline \hline June, 1992 & $\begin{array}{l}\text { City of Taft } \\
\text { Agricultural Lease }\end{array}$ & 18D & 167 & $\begin{array}{l}\text { One (1) } \\
\text { Prehistoric lithic } \\
\text { scatter. }\end{array}$ & Zero (0) & $\begin{array}{l}\text { Not eligible for } \\
\text { NRHP }^{\mathrm{b}}\end{array}$ \\
\hline June, 1993 & $\begin{array}{l}\text { Three alternative } \\
\text { powerline routes } \\
\text { on NPR-1 }\end{array}$ & $5 \mathrm{M} / 6 \mathrm{M}$ & $\begin{array}{l}108 \\
(25.14 / \\
\text { NPR-1) }\end{array}$ & $\begin{array}{l}\text { Two (2) } \\
\text { Prehistoric lithic } \\
\text { and shell scatters }\end{array}$ & $\begin{array}{l}\text { One (1) } \\
\text { Prehistoric } \\
\text { flake. }\end{array}$ & Comments pending \\
\hline
\end{tabular}

a SHPO = California State Historic Preservation Officer

b NRHP = National Register of Historic Places

${ }^{c}$ Found on ARCO Oil and Gas Company property

\subsubsection{Cultural Resource Compliance}

The second draft of the Cultural Resource Management Plan for NPR-1 was completed in FY93. The first draft was completed late in FY92. Shortly after its completion it was decided by DOE and CPDN to revise the Cultural Resource Management Plan to follow DOE draft "Environmental Guidelines for Development of Cultural Resource Management Plans" dated June 1992. DOE, CPDN, and EG\&G/EM met with SHPO in February 1993 to receive guidance on the content of the document. The second draft of the Cultural Resource Management Plan was completed in June 1993 and transmitted for comment to DOE, CPDN, Research Management Consultants, Inc. (RMCI), and Bechtel Petroleum Operations, Inc. (BPOI). Comments were received from CPDN, RMCI, and BPOI in September 1993. A briefing on the content of the document was presented on September 8, 1993. Currently, review comments are being incorporated prior to submission of the document to SHPO. 


\section{HABITAT RECLAMATION AND MANAGEMENT}

\subsection{RECLAMATION OF DISTURBED LANDS}

Approximately 36 acres ( 71 sites) of disturbed lands were selected for reclamation in fall 1993. This includes 19 acres of abandoned wells or well pad sumps, one-half acre of unused roadways or pipeline rights-of-way, about four acres of soil borrow sites, and 12 acres of cut or fill slopes. The majority of the sites were identified by BPOI as a result of either construction or abandonment activities during the year.

Average costs for reclamation work for the last nine years are reported in Table 16. Average cost for materials is approximately $\$ 415 /$ acre and $\$ 1,549 /$ acre for the reclamation subcontractor. Total revegetation costs were $\$ 1,693 /$ acre this year, compared with a nine-year average of $\$ 1,964 /$ acre.

Table 16. Cost of revegetating disturbed lands on the Naval Petroleum Reserves in California.

\begin{tabular}{|c|c|c|c|c|c||}
\hline Fiscal Year & $\begin{array}{c}\text { No. } \\
\text { Sites }\end{array}$ & $\begin{array}{c}\text { No. } \\
\text { Acres }\end{array}$ & $\begin{array}{c}\text { Materials } \\
\text { (\$/acre) }\end{array}$ & $\begin{array}{c}\text { Contract } \\
\text { (\$/acre) }\end{array}$ & $\begin{array}{c}\text { Total Costs } \\
\text { (\$/acre) }\end{array}$ \\
\hline \hline 1985 & 148 & 93 & 935.00 & $1,914.00$ & $2,849.00$ \\
\hline 1986 & 272 & 112 & 643.00 & $2,045.00$ & $2,688.00$ \\
\hline 1987 & 191 & 110 & 236.00 & $1,818.00$ & $2,054.00$ \\
\hline 1988 & 396 & 206 & 413.00 & $1,568.00$ & $1,981.00$ \\
\hline 1989 & 173 & 116 & 207.00 & 851.00 & $1,058.00$ \\
\hline 1990 & 166 & 72 & 448.00 & $1,369.00$ & $1,817.00$ \\
\hline 1991 & 198 & 84 & 300.00 & $1,444.00$ & $1,744.00$ \\
\hline 1992 & 184 & 70 & $295.00^{\mathrm{a}}$ & $1,500.00^{\mathrm{a}}$ & $1,795.00$ \\
\hline 1993 & 71 & 36 & $260.00^{\mathrm{a}}$ & $1,433.00^{\mathrm{a}}$ & $1,693.00$ \\
\hline \hline Totals & 1,799 & 899 & \multicolumn{4}{|l}{} \\
\hline 9-Yr Average & & \multicolumn{5}{|l}{} & \multicolumn{3}{|l}{} \\
\hline
\end{tabular}

${ }^{a}$ Cost of straw included in revegetation contract in 1992 and 1993. 
Specifications were prepared and used to procure the services of a reclamation subcontractor to perform site preparation, seeding, and mulching. Reclamation work will be completed by mid-December 1993.

\subsection{MONITORING RECLAMATION SUCCESS}

Reclamation on NPR-1 has been monitored since 1987. The objective of the monitoring program is to (1) evaluate plant establishment, (2) establish reclamation success standards for the current year, (3) determine the number of sites that have met current reclamation suceess standards, (4) evaluate the overall status of sites reclaimed since 1985, and to refine reclamation techniques, if necessary. Quantitative estimates of vascular plant cover and shrub density were determined for 16 reference sites located on NPR-1. The same data were collected from sites reclaimed in 1988 and compared with the reference site data to determine reclamation success. Vascular plant cover and shrub density were also measured on a subsample of sites reclaimed each year since 1985.

\subsubsection{Plant Establishment}

Total vascular plant cover and composition were determined for 212 sites revegetated in 1991 and 184 sites revegetated in 1992. In 1993, the average vascular plant cover on sites reclaimed in 1991 was $53 \%$ ( $\mathrm{SE}=1.5$ ), slightly higher than it was in 1992 (Table 17). The relative cover for grass species was about the same in 1993 as it was in 1992. However, relative shrub cover increased from 7\% ( $\mathrm{SE}=0.6)$ to $21 \%(\mathrm{SE}=1.2)$ from 1992 to 1993 , and forb cover decreased from $41 \%(\mathrm{SE}=1.4)$ to $26 \%$ (SE $=1.1$ ). Approximately $19 \%$ of the sites have been disturbed since they were reclaimed in 1991; 7\% were disturbed during the last year.

Average vascular plant cover on sites revegetated in 1992 was 35\%. Approximately $63 \%$ of the total cover was attributable to grasses. The remaining $37 \%$ was about equally divided between shrubs and forbs. Only $9 \%$ of the sites have been disturbed since revegetation.

Table 17. Results of qualitative evaluations on sites reclaimed in 1991 and 1992. Standard errors are in parentheses.

\begin{tabular}{|c|c|c|c|c|c|c|c|}
\hline \multirow{2}{*}{$\begin{array}{c}\text { Year } \\
\text { Reclaimed }\end{array}$} & \multirow{2}{*}{$\begin{array}{c}\text { Year } \\
\text { Monitored }\end{array}$} & \multirow{2}{*}{$\begin{array}{l}\text { Sample } \\
\text { Size }\end{array}$} & \multirow{2}{*}{$\begin{array}{c}\text { Total } \\
\text { Vascular } \\
\text { Plant Cover } \\
(\%) \\
\end{array}$} & \multicolumn{3}{|c|}{ Relative Cover (\%) } & \multirow{2}{*}{$\begin{array}{c}\text { Percent } \\
\text { Disturbed }\end{array}$} \\
\hline & & & & Shrub & Grass & Forb & \\
\hline \multirow[t]{2}{*}{1991} & 1992 & 212 & $\begin{array}{l}51 \\
(1.6) \\
\end{array}$ & $\begin{array}{l}7 \\
(0.6) \\
\end{array}$ & $\begin{array}{l}52 \\
(1.5) \\
\end{array}$ & $\begin{array}{l}41 \\
(1.4)\end{array}$ & 12 \\
\hline & 1993 & 212 & $\begin{array}{l}53 \\
(1.5) \\
\end{array}$ & $\begin{array}{l}21 \\
(1.2) \\
\end{array}$ & $\begin{array}{l}53 \\
(1.1)\end{array}$ & $\begin{array}{l}26 \\
(1.1)\end{array}$ & 19 \\
\hline 1992 & 1993 & 184 & $\begin{array}{l}31 \\
(1.2)\end{array}$ & $\begin{array}{l}17 \\
(1.6)\end{array}$ & $\begin{array}{l}63 \\
(1.9)\end{array}$ & $\begin{array}{l}20 \\
(1.2)\end{array}$ & 9 \\
\hline
\end{tabular}




\subsubsection{Reclamation Success}

\subsubsection{Reclamation Success Standards}

Plant cover and shrub density were sampled on 16 reference sites. Eight of the 16 reference sites are located on north slopes and eight are located on south slopes. Plant cover and shrub density estimates for the reference sites are used to establish reclamation success standards. Seventy percent of the average cover and average shrub density for the north- and south-slope reference sites are standards for determining reclamation success. If both vascular plant cover and shrub density on a revegetated site meets or exceeds these standards, the site is considered successfully reclaimed.

In 1993 , the estimated total vascular plant cover on north slopes was $72 \%$, which was less than it was in 1992 (85\%), but higher than the $46 \%$ percent cover recorded in 1991 (Table 18). Reclamation success standards for cover for 1993 was $50.7 \%(70 \% \times 72.4 \%=50.7 \%)$ for north slopes and $37.5 \%(70 \% \times 53.5 \%=37.5 \%)$ for south slopes. Total vascular plant cover on south slopes averaged an estimated $54 \%$ in 1993 , which was slightly less than it was in 1992 (59\%), but higher than the $24 \%$ percent cover recorded in 1991.

Shrub density on north-slope sites decreased from 131 shrubs/ha in 1992 to 108 shrubs/ha in 1993. The success standard for shrub density in 1993 was 75 shrubs/ha on north slopes and 136 shrubs/ha on south slopes (Table 19). Shrub density on south-slope sites was 195 shrubs/ha in 1993, slightly lower than the 197 shrubs/ha recorded in 1992.

Table 18. Average total plant cover (\%) and success standards on eight north-slope and eight south-slope reference sites. Standard errors are in parentheses.

\begin{tabular}{|c|c|c|c|c||}
\hline \multirow{2}{*}{ Year } & \multicolumn{2}{|c|}{ North Slope } & \multicolumn{2}{c|}{ South Slope } \\
\cline { 2 - 5 } & Cover & $\begin{array}{c}\text { Success } \\
\text { Standard }\end{array}$ & Cover & $\begin{array}{c}\text { Success } \\
\text { Standard }\end{array}$ \\
\hline \hline 1991 & $\begin{array}{c}45.9 \\
(2.2)\end{array}$ & 32.1 & $\begin{array}{c}23.8 \\
(3.4)\end{array}$ & 16.7 \\
\hline 1992 & $\begin{array}{c}84.5 \\
(5.0)\end{array}$ & 59.2 & $\begin{array}{c}59.0 \\
(5.4)\end{array}$ & 41.3 \\
\hline 1993 & $\begin{array}{c}72.4 \\
(5.2)\end{array}$ & 50.7 & $\begin{array}{c}53.5 \\
(3.9)\end{array}$ & 37.5 \\
\hline
\end{tabular}


Table 19. Average shrub density (no./ha) and success standards on eight north-slope and eight south-slope reference sites. Standard errors are in parentheses.

\begin{tabular}{|c|c|c|c|c||}
\hline \multirow{2}{*}{ Year } & \multicolumn{2}{|c|}{ North Slope } & \multicolumn{2}{c|}{ South Slope } \\
\cline { 2 - 5 } & $\begin{array}{c}\text { Shrub Density } \\
\text { (\#/ha) }\end{array}$ & $\begin{array}{c}\text { Success } \\
\text { Standard }\end{array}$ & $\begin{array}{c}\text { Shrub Density } \\
\text { (\#/ha) }\end{array}$ & $\begin{array}{c}\text { Success } \\
\text { Standard }\end{array}$ \\
\hline \hline 1991 & $\begin{array}{c}69.6 \\
(15.3)\end{array}$ & 48.7 & $\begin{array}{c}143.3 \\
(23.8)\end{array}$ & 100.3 \\
\hline 1992 & $\begin{array}{l}131.0 \\
(30.2)\end{array}$ & 91.7 & $\begin{array}{c}196.5 \\
(47.3)\end{array}$ & 137.6 \\
\hline 1993 & $\begin{array}{l}107.5 \\
(30.2)\end{array}$ & 75.2 & $\begin{array}{c}194.5 \\
(33.5)\end{array}$ & 136.1 \\
\hline
\end{tabular}

\subsubsection{1988 Sites}

Five years after a site is revegetated, it is sampled to determine vascular plant cover and shrub density, which are used to evaluate reclamation success. During the spring of 1993, 359 of 398 sites reclaimed in 1988 were qualitatively evaluated as to whether or not success standards were met. The qualitative data are useful in evaluating the overall condition of reclamation sites and quickly identifies those sites least likely to meet success standards, so that effort is not expended to quantitatively sample sites that will obviously not meet success standards. Based on the qualitative data collected from sites reclaimed in 1988, average vascular plant cover increased dramatically over the last five growing seasons (Table 20). Total vascular cover increased from $6 \%$ and $7 \%$ the first two growing seasons to $50 \%$ in the fifth growing season. The low vascular plant cover the first two years is probably due to below normal precipitation during the 1988 and 1989 growing seasons.

Of the 359 sites that were qualitatively evaluated in the spring of 1993, 243 (105 north-slope sites and 138 south-slope sites) appeared to meet reclamation success criteria and were subsequently quantitatively sampled to document actual success. The remaining 155 sites will be monitored periodically in future years and remedial reclamation will occur as necessary. 
Table 20. Results of qualitative evaluations of 398 sites reclaimed in 1988. Standard errors are in parentheses.

\begin{tabular}{|c|c|c|c|c|c|c||}
\hline \multirow{2}{*}{ Year } & \multirow{2}{*}{$\begin{array}{c}\text { Number of } \\
\text { Sites } \\
\text { Monitored }\end{array}$} & $\begin{array}{c}\text { Total } \\
\text { Vascular } \\
\text { Plant Cover }\end{array}$ & \multicolumn{3}{|c||}{ Relative Cover (\%) } & \multirow{2}{*}{$\begin{array}{c}\text { Percent } \\
\text { Disturbance }\end{array}$} \\
\cline { 4 - 6 } 1989 & 398 & $\begin{array}{c}7.2 \\
(0.4)\end{array}$ & $\begin{array}{c}37.6 \\
(1.4)\end{array}$ & $\begin{array}{c}37.9 \\
(1.3)\end{array}$ & $\begin{array}{c}24.6 \\
(1.1)\end{array}$ & 12 \\
\hline 1990 & 398 & $\begin{array}{c}6.4 \\
(0.4)\end{array}$ & $\begin{array}{c}64.6 \\
(1.7)\end{array}$ & $\begin{array}{c}18.4 \\
(1.3)\end{array}$ & $\begin{array}{c}12.6 \\
(0.9\end{array}$ & 15 \\
\hline 1993 & 359 & $\begin{array}{c}50.4 \\
(1.1)\end{array}$ & $\begin{array}{c}32.4 \\
(1.1)\end{array}$ & $\begin{array}{c}45.6 \\
(0.9)\end{array}$ & $\begin{array}{c}21.3 \\
(0.7)\end{array}$ & 13 \\
\hline
\end{tabular}

Vascular plant cover and shrub density met or exceeded success standards on 40 of the 105 north-slope sites (38\%) and 70 of 138 south-slope sites (51\%). Of the 398 sites reclaimed in $1988,28 \%$ of the sites met success standards after five growing seasons.

\subsubsection{Subsample Sites}

Total vascular plant cover and shrub density are determined annually on approximately $10 \%$ of the sites that have been reclaimed on NPR-1 between 1985 and 1992 . The sites are randomly selected and represent both north and south slopes. The data are used to determine the amount of time required for vascular plant cover on a revegetated site to approximate cover on undisturbed sites. In 1993 a total of 257 sites were sampled, which includes sites reclaimed under EG\&G/EM's habitat reclamation program and those sites reclaimed by BPOI under their contemporaneous reclamation program carried out between 1989 and 1991. Current year's estimates for both north and south slopes are slightly lower than they were in 1992 (Table 21).

Average vascular plant cover for sites reclaimed over the last eight years ranges from around $20 \%$ for 1991 sites to near $50 \%$ for 1985 sites. Vascular plant cover on sites reclaimed as recently as 1990 is near $40 \%$. Precipitation during the last two growing seasons was above normal, which may account for the quick plant establishment on the more recently revegetated sites. 
Table 21. Average vascular plant cover on a subsample of sites reclaimed on Naval Petroleum Reserve No. 1 between 1985 and 1992.

\begin{tabular}{|c|c|c|c|c|c|c|}
\hline \multirow{3}{*}{$\begin{array}{l}\text { Year Sites } \\
\text { Reclaimed }\end{array}$} & \multirow[b]{3}{*}{ Aspect } & \multirow{3}{*}{$\begin{array}{c}\text { No. } \\
\text { Sites } \\
\text { Sampled }\end{array}$} & \multicolumn{4}{|c|}{ Average Cover (\%) } \\
\hline & & & \multicolumn{2}{|c|}{1993} & \multicolumn{2}{|c|}{1992} \\
\hline & & & $\bar{x}$ & SE & $\bar{x}$ & SE \\
\hline \multirow[t]{2}{*}{1985} & North & 7 & 47.6 & 6.4 & 61.0 & 3.7 \\
\hline & South & 8 & 50.4 & 7.7 & 60.3 & 6.2 \\
\hline \multirow[t]{2}{*}{1986} & North & 8 & 45.1 & 10.4 & 48.8 & 5.0 \\
\hline & South & 21 & 39.3 & 3.9 & 50.2 & 4.4 \\
\hline \multirow[t]{2}{*}{1987} & North & 10 & 40.0 & 6.1 & 45.6 & 6.6 \\
\hline & South & 15 & 46.9 & 5.8 & 57.9 & 5.2 \\
\hline \multirow[t]{2}{*}{1988} & North & 16 & 45.9 & 5.3 & 42.3 & 5.2 \\
\hline & South & 26 & 33.4 & 5.2 & 46.4 & 4.4 \\
\hline \multirow[t]{2}{*}{1989} & North & 8 & 31.1 & 10.2 & 47.8 & 8.1 \\
\hline & South & 14 & 38.7 & 6.3 & 36.4 & 7.2 \\
\hline \multirow[t]{2}{*}{1990} & North & 31 & 41.6 & 3.9 & 42.4 & 4.1 \\
\hline & South & 27 & 35.3 & 4.7 & 37.9 & 3.6 \\
\hline \multirow[t]{2}{*}{1991} & North & 23 & 35.2 & 4.6 & 40.2 & 5.3 \\
\hline & South & 18 & 24.9 & 6.0 & 39.5 & 5.5 \\
\hline \multirow[t]{2}{*}{1992} & North & 5 & 21.8 & 5.9 & & \\
\hline & South & 20 & 18.0 & 2.8 & & \\
\hline
\end{tabular}

\subsubsection{4 $\quad \underline{\text { Research Studies }}$}

In FY90, a study was initiated to evaluate whether reseeding of large burned areas improved wildlife habitat. As part of that study, the use of shrub transplants on burned lands was evaluated. Fourwing saltbush (Atriplex canescens), California buckwheat (Eriogonum fasciculatum), and bladderpod (Isomeris arborea) were transplanted onto three seven-to-eight year-old (old) and three three-to-five year-old (new) burned areas on NPR-1. Survival of the shrub transplants has been monitored the last three years. Fourwing saltbush showed the 
greatest survival rate after three years (44\%), a decline from the survival rate after two years $(84 \%)$. Survival rates for the other two species also declined (Table 22).

The vigor of the transplants that have survived was much lower that it was in 1992. Notes and comments recorded during sampling of the transplants suggest that the major cause for the decline in both survival and vigor was herbivory. Many, if not all, of the fourwing saltbush and California buckwheat transplants had been browsed, some back to the crown root. It was also observed that individuals of each of the species were in flower or had set seed.

Table 22. Shrub transplant survival rates on burned sites on Naval Petroleum Reserve No. 1 for 1992 and 1993.

\begin{tabular}{||l|l|c|c|c||}
\hline \multirow{2}{*}{ Treatment } & \multirow{2}{*}{ Shrub Species } & \multicolumn{3}{|c|}{ Average Survival (\%) } \\
\cline { 3 - 5 } & & 1991 & 1992 & 1993 \\
\hline \hline \multirow{2}{*}{$\begin{array}{l}\text { Old Burn } \\
\text { (7-8 years old) }\end{array}$} & Fourwing saltbush & 97 & 89 & 78 \\
\cline { 2 - 5 } & California Buckwheat & 45 & 57 & 40 \\
\cline { 2 - 5 } & Bladderpod & 66 & 49 & 48 \\
\hline \multirow{3}{*}{$\begin{array}{l}\text { New Burn } \\
\text { (3-5 years old) }\end{array}$} & Fourwing saltbush & 96 & 80 & 8 \\
\cline { 2 - 5 } & California Buckwheat & 30 & 35 & 13 \\
\cline { 2 - 5 } & Bladderpod & 35 & 34 & 17 \\
\hline \multirow{3}{*}{ Total } & Fourwing saltbush & 97 & 84 & 44 \\
\cline { 2 - 5 } & California Buckwheat & 50 & 46 & 26 \\
\cline { 2 - 5 } & Bladderpod & 36 & 41 & 32 \\
\hline
\end{tabular}

The results to date suggest that if the ultimate goal of transplanting is to establish a certain density of shrubs, initial plant densities two to three time the standard rate may be required. However, if the goal is simply to reestablish shrub species on sites previously devoid of shrubs, these three species could be planted and over time would provide a source of seed for recolonization of an area.

The difference in transplant survival between the old and new burns was unexpected. It was originally hypothesized that the transplants would not survive as well in the old burn areas because of the dominance of red brome. The new burn areas were relatively free of dense swards of red brome and transplant survival was expected to be high due to reduced competition for moisture and nutrients. The sparse vegetation found on new burn areas may actually have contributed to lower survival rates, as open vegetation may have exposed transplanted shrubs to increased herbivory. 


\section{RESEARCH AND DEVELOPMENT}

\subsection{SUMMARY OF COYOTE DATA}

Coyotes are competitors with San Joaquin kit foxes and have been identified as the primary cause of kit fox mortality at NPRC. As a result, data have been collected on coyote populations at NPRC. These data were summarized in a draft topical report that included information on coyote population trends, number of coyotes killed during the 1985-90 Coyote Control Program, morphometric and mass measurements, prevalence of viral antibodies, and food habits.

In addition to the data summaries that were included in the draft topical report, more detailed analyses of coyote food habits, morphometric measurements and mass dynamics, and prevalence of viral antibodies were conducted. Results of the food habit analyses were summarized in the FY92 Annual Report. Morphometric measurements collected from coyotes killed during the Coyote Control Program included total length, tail length, hind-foot length, earfrom-notch length, and mass. Mean measurements indicated that coyotes in the southern San Joaquin Valley are "medium-sized" compared with coyotes from other regions. Monthly means for pups suggested that pups grow most rapidly in spring and early summer, and that growth patterns were similar for males and females. Mean measurements obtained from pups collected after November did not differ significantly from those for yearlings or adults indicating that most structural growth occurs in the first year (Table 23). Mean mass did not vary among age classes for females, but did vary among age classes for males with adult mass being significantly higher than that of yearlings or pups. Contrary to results from investigations conducted elsewhere, mean mass of adult and yearling coyotes did not vary among seasons (Table 24). This lack of seasonal mass dynamics may be a function of mild winters and consistent use of lagomorphs as the predominant food item in all seasons.

Blood samples also were collected from coyotes killed during the control program and tested for the presence of antibodies to canine parvovirus (CPV), canine distemper virus (CDV), and infectious canine hepatitis virus (ICH). Overall prevalence of antibodies to CPV, $\mathrm{CDV}$, and ICH was $66.2 \%, 37.3 \%$, and $67.8 \%$, respectively. Prevalence varied among years for CPV and CDV (Table 25). For all three diseases, prevalence did not vary between sexes, but prevalence did vary among age-classes and was lowest for pups (Table 26). However, some pups sampled in May of their birth year had antibodies indicating either acquisition of maternal antibodies through placental or colostral transfer, or early exposure to the viruses. Incidence of disease and the effects of CPV, CDV, and ICH on coyote survival and population dynamics in the southern San Joaquin Valley are unknown. Coyotes are a potential source of viral exposure for kit foxes, but interspecific transmission rates are unknown. 
Table 23. Age-class comparison of mean morphometric measurements and body mass among coyotes collected from December to March, Naval Petroleum Reserves in California, Kern County, California, 1985 - 1990. Standard errors are in parentheses.

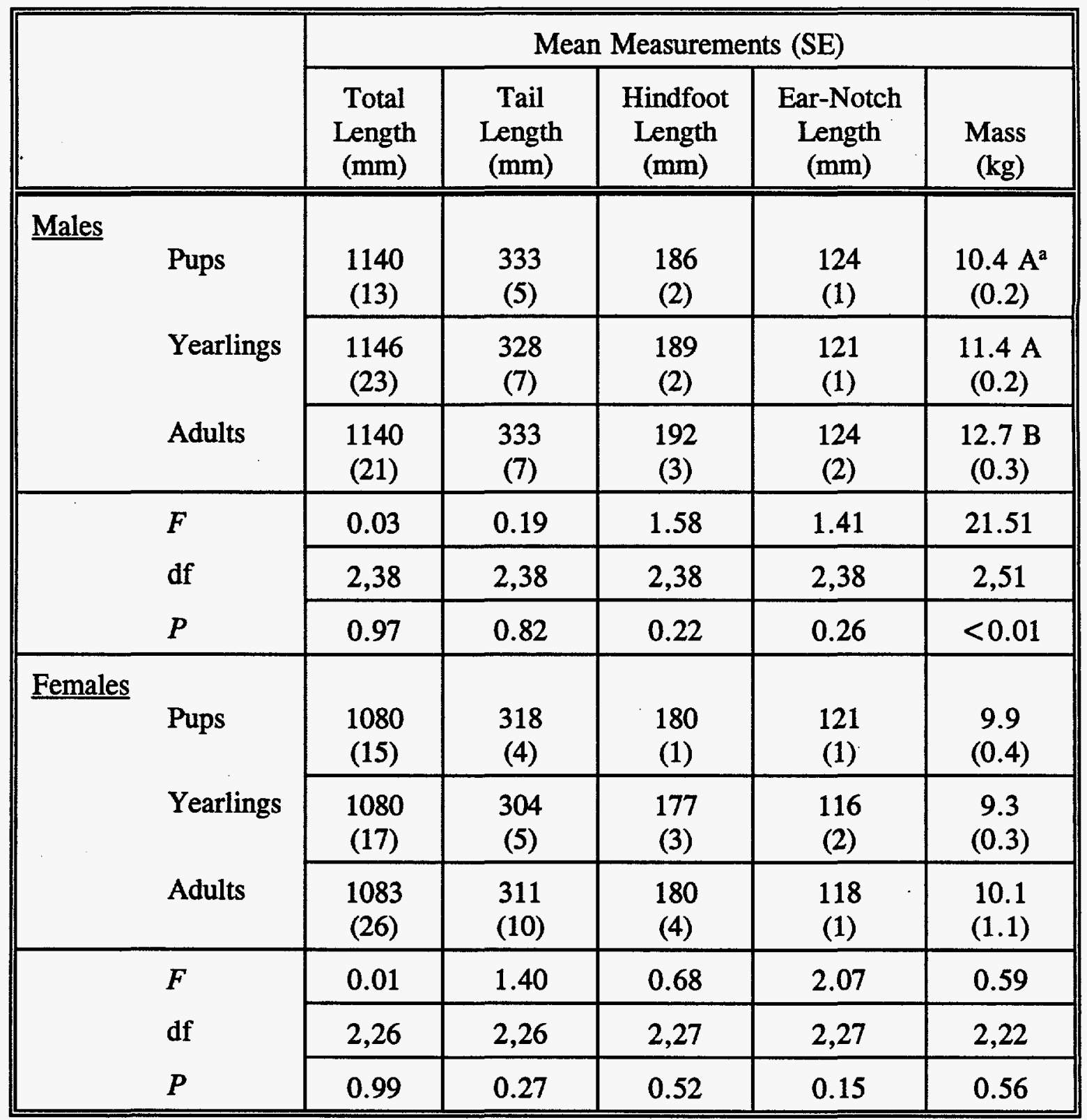

a Means followed by the same letter are not significantly different. 
Table 24. Seasonal comparison of mean body mass for adult and yearling coyotes, Naval Petroleum Reserves in California, Kern County, California, 1985 - 1990.

\begin{tabular}{|c|c|c|c|c|c|c|c|c|}
\hline & & \multicolumn{4}{|c|}{$\begin{array}{c}\text { Mean Mass (kg) } \\
\text { (SE) }\end{array}$} & \multirow{2}{*}{$F$} & \multirow{2}{*}{ df } & \multirow{2}{*}{$P$} \\
\hline & & Spring & Summer & Fall & Winter & & & \\
\hline \multirow[t]{2}{*}{$\underline{\text { Adults }}$} & Males & $\begin{array}{l}12.0 \\
(0.3)\end{array}$ & $\begin{array}{l}12.1 \\
(0.4)\end{array}$ & $\begin{array}{c}11.5 \\
(0.4)\end{array}$ & $\begin{array}{l}12.3 \\
(0.4)\end{array}$ & 1.02 & 3,78 & 0.39 \\
\hline & Females & $\begin{array}{l}10.0 \\
(0.3)\end{array}$ & $\begin{array}{c}9.8 \\
(0.2)\end{array}$ & $\begin{array}{l}10.9 \\
(0.4)\end{array}$ & $\begin{array}{l}10.0 \\
(1.0)\end{array}$ & 1.67 & 3,49 & 0.19 \\
\hline \multirow[t]{2}{*}{ Yearlings } & Males & $\begin{array}{l}10.8 \\
(0.4)\end{array}$ & $\begin{array}{l}10.4 \\
(0.3)\end{array}$ & $\begin{array}{l}11.4 \\
(0.4)\end{array}$ & $\begin{array}{l}11.7 \\
(0.4) \\
\end{array}$ & 1.54 & 3,30 & 0.22 \\
\hline & Females & $\begin{array}{c}9.2 \\
(0.3)\end{array}$ & $\begin{array}{c}9.4 \\
(0.4)\end{array}$ & $\begin{array}{c}9.4 \\
(0.5)\end{array}$ & $\begin{array}{l}9.6 \\
(0.3)\end{array}$ & 0.16 & 3,29 & 0.92 \\
\hline
\end{tabular}

Table 25. Annual prevalence of antibodies to canine parvovirus (CPV), canine distemper virus (CDV), and infectious canine hepatitis virus (ICH) among coyotes at the Naval Petroleum Reserves in California, Kern County, California, from 1985-1990.

\begin{tabular}{||c|c|c|c|c|c|c||}
\hline \multirow{2}{*}{ Year } & \multicolumn{2}{|c|}{ CPV } & \multicolumn{2}{c|}{ CDV } & \multicolumn{2}{c||}{ ICH } \\
\cline { 2 - 7 } & $n$ & $\%$ & $n$ & $\%$ & $n$ & $\%$ \\
\hline \hline 1985 & 26 & 76.9 & 26 & 65.4 & 26 & 84.6 \\
\hline 1986 & 32 & 46.9 & 32 & 37.5 & 32 & 68.8 \\
\hline 1987 & 7 & 85.7 & 7 & 28.6 & 7 & 71.4 \\
\hline 1988 & 31 & 48.4 & 31 & 25.8 & 31 & 67.7 \\
\hline 1989 & 51 & 80.4 & 50 & 34.0 & 52 & 57.7 \\
\hline 1990 & 4 & 75.0 & 4 & 0.0 & 4 & 75.0 \\
\hline$G$ & & 17.15 & & 14.45 & & 6.32 \\
\hline df & & 5 & & 5 & & 5 \\
\hline$P$ & & $<0.01 *$ & & $0.01 *$ & & 0.28 \\
\hline
\end{tabular}

* Statistically significant $P$ value. 
Table 26. Age-class-specific prevalence of antibodies to canine parvovirus (CPV), canine distemper virus (CDV), and infectious canine hepatitis virus (ICH) among coyotes at the Naval Petroleum Reserves in California, Kern County, California, from 19851990.

\begin{tabular}{|c|c|c|c|c|c|c||}
\hline \multirow{2}{*}{ Age Class } & \multicolumn{2}{|c|}{ CPV } & \multicolumn{2}{c|}{ CDV } & \multicolumn{2}{c|}{ ICH } \\
\cline { 2 - 7 } & $n$ & $\%$ & $n$ & $\%$ & $n$ & $\%$ \\
\hline \hline Pup (<1 year) & 47 & $38.3 \mathrm{~A}^{\mathrm{a}}$ & 47 & $14.9 \mathrm{~A}$ & 48 & $47.9 \mathrm{~A}$ \\
\hline Yearling (1 year) & 37 & $89.2 \mathrm{~B}$ & 36 & $36.1 \mathrm{~B}$ & 37 & $54.1 \mathrm{~A}$ \\
\hline Adult (>2 years) & 67 & $73.1 \mathrm{~B}$ & 67 & $53.7 \mathrm{~B}$ & 67 & $89.6 \mathrm{~B}$ \\
\hline$G$ & & 27.26 & & 19.05 & & 28.73 \\
\hline df & & 2 & & 2 & & 2 \\
\hline$P$ & & $<0.01$ & & $<0.01$ & & $<0.01$ \\
\hline
\end{tabular}

a Means followed by the same letter are not significantly different.

\subsection{DISTRIBUTION AND ABUNDANCE OF KIT FOXES ON NPRC}

Data collected from live-trapped foxes over the last 12 years have been used to estimate the size of the fox population at NPRC. However, fox captures have not been evenly distributed throughout NPRC and opportunities exist for investigating why foxes are consistently captured in some areas but never captured in other locations. In FY93, a study was initiated to determine the influence of land use and physiographic and biological factors on the distribution and abundance of kit foxes at NPRC. By determining if fox abundance and persistence at trap sites are correlated with variables such as oil field development, topographic ruggedness and coyote and lagomorph abundance, the relative influence of these variables on fox distribution can be assessed.

During FY93, several data files were developed or formatted to allow for efficient retrieval of information. Lagomorph data were copied to a file and summarized so that the number of lagomorphs can be related to fox abundance and other variables on a quarter section basis. The number of foxes captured per trap site was determined for different areas and time periods. Indices of topographic ruggedness were determined for each quarter section on NPRC by measuring the length of contour lines on 7.5 minute topographic maps. 
Estimates of area developed within each quarter section was determined by placing transparent dot grids over 1988 aerial photographs and determining the proportion of dots that intercepted development. Plans for FY94 are to complete data analyses and initiate writing of a report summarizing the results.

\subsection{EFFECTS OF RESEEDING BURNED AREAS ON SMALL MAMMAL AND LAGOMORPH POPULATIONS}

In some plant communities, shrubs become reestablished after a fire via seed germination or crown sprouting. However, the dominant shrub on NPR-1, desert saltbush, does not crown sprout and increased germination on burned areas has not been observed. On several of the larger burned sites on NPR-1, shrub cover has been significantly reduced in comparison with pre-fire conditions, or with adjacent unburned lands.

In fall 1990, approximately 350 acres of land burned in 1988 were interseeded with a mix of shrubs, grass, and forb. The mix consisted mostly of shrub seed. The area was seeded in an attempt to reestablish shrub species and to increase overall plant diversity before the site became dominated by annual species. It was hypothesized that an increase in shrubs and species diversity would increase small mammal and lagomorph populations, which are prey for the endangered San Joaquin kit fox. The effectiveness of seeding burned areas was determined through comparison with an adjacent unseeded burned area (300 acres) and an unburned control area (400 acres). Vegetation was monitored annually, while small mammal populations were monitored seasonally.

\subsubsection{Vegetation}

Vegetation on each of the three study areas was monitored in the spring of each year along six permanent $200-\mathrm{m}$ transects placed in a stratified random design. The vegetation characteristics measured included: (1) plant, litter, and bare ground cover; (2) species density; (3) herbaceous production; and (4) plant diversity.

In 1993, the average percent cover was not different among the three study areas ( $F$ $=0.03$, df $=2,15, P=0.97$ ) (Table 27). Mean vegetative cover decreased on all three study areas from 1992 levels, with the greatest decrease occurring on the unburned control area. Mean grass and forb density (no. $\left./ \mathrm{m}^{2}\right)$ was also not different among the three study areas $(F=$ 0.06 , df $=2,15, P=0.95$ ) (Table 27). Mean grass and forb density increased on all three study areas from 1992 levels, with the greatest increase occurring on the unburned control area. Increases in mean grass and forb density on all study areas was probably the result of high rainfall in January and February 1993 (Section 2.9), which tends to favor germination of herbaceous species. 
Table 27. Mean vegetative cover, density, production, and plant diversity for burn study experimental plots on Naval Petroleum Reserve No. 1, Kern County, California, Spring 1992 and 1993.

\begin{tabular}{|c|c|c|c|c|c|c|c|c|c|c|c|}
\hline \multirow{2}{*}{ Year } & \multirow[t]{2}{*}{ Study Area } & \multicolumn{2}{|c|}{$\begin{array}{l}\text { Vegetative } \\
\text { Cover }(\%)\end{array}$} & \multicolumn{2}{|c|}{$\begin{array}{l}\text { Shrub Density } \\
\text { (no./ha) }\end{array}$} & \multicolumn{2}{|c|}{$\begin{array}{c}\text { Grass/Forb } \\
\text { Density (no. } / \mathrm{m}^{2} \text { ) }\end{array}$} & \multicolumn{2}{|c|}{$\begin{array}{c}\text { Herbaceous } \\
\text { Production (kg/ha) }\end{array}$} & \multicolumn{2}{|c|}{$\begin{array}{l}\text { Plant Diversity } \\
\text { (No. Species) }\end{array}$} \\
\hline & & $\bar{x}$ & SE & $\bar{x}$ & SE & $\bar{x}$ & SE & $\bar{x}$ & SE & All Species & Seeded Species \\
\hline \multirow[t]{3}{*}{1992} & $\begin{array}{l}\text { Seeded } \\
\text { Burn }\end{array}$ & 65.3 & 2.3 & 1,042 & 312 & $346.3 \mathrm{~B}$ & 49.1 & 1,197 & 116 & 26 & 5 \\
\hline & $\begin{array}{l}\text { Unseeded } \\
\text { Burn }\end{array}$ & 62.9 & 4.8 & 483 & 173 & $519.9 \mathrm{~A}$ & 49.6 & 1,121 & 135 & 22 & 3 \\
\hline & $\begin{array}{l}\text { Unburned } \\
\text { Control }\end{array}$ & 65.5 & 2.5 & 1,000 & 117 & $324.8 \mathrm{~B}$ & 20.1 & 1,554 & 213 & 26 & 4 \\
\hline \multirow[t]{3}{*}{1993} & \begin{tabular}{|l} 
Seeded \\
Burn \\
\end{tabular} & 57.8 & 3.6 & $3,475 \mathrm{~A}^{\mathrm{a}}$ & 745 & 729.7 & 73.2 & $2,719 \mathrm{~A}$ & 224 & 42 & 5 \\
\hline & $\begin{array}{l}\text { Unseeded } \\
\text { Burn }\end{array}$ & 58.8 & 3.5 & 892 B & 440 & 697.9 & 117.6 & $1,932 \mathrm{AB}$ & 316 & 39 & 4 \\
\hline & $\begin{array}{l}\text { Unburned } \\
\text { Control }\end{array}$ & 57.5 & 4.7 & $1,112 \mathrm{~B}$ & 303 & 752.1 & 111.7 & $1,470 \mathrm{~B}$ & 88 & 43 & 3 \\
\hline
\end{tabular}

${ }^{a}$ Means followed by the same letter within a column are not significantly different $(P>0.05)$ 
Mean shrub density (no./ha) was significantly higher on the seeded burn area than on either the unseeded burn area or the unburned control area $(F=7.2, \mathrm{df}=2,15$, $P=0.006$ ) (Table 27). Mean shrub density increased on both the seeded and unseeded burn area over 1992 levels, but decreased on the unburned control over the same period.

Mean herbaceous production ( $\mathrm{kg} / \mathrm{ha}$ ) was significantly higher on the seeded burn area than on the unburned control area $(F=7.6$, df $=2,15, P=0.006)$ (Table 27). Mean herbaceous production on the unseeded burn area was not different than either the seeded burn area or the unburned control area. Production increased on both the seeded and unseeded burn areas, but decreased on the unburned control area. Mean grass and forb density more than doubled on the unburned control between 1992 and 1993, while production decreased over the same period.

While some differences were detected, the vegetative characteristics of the three treatment areas are rather similar. Mechanical seeding did result in a significantly higher shrub density on the seeded burn. However, small differences in plant species diversity indicate that seeding probably did not significantly improve species diversity on the seeded burn area.

\subsubsection{Small Mammal Populations}

Small mammal populations were monitored using live-traps placed along six permanent traplines on each of the three study areas in November 1992, March 1993, and July 1993. In November 1992, 50 Sherman live-traps were operated for three consecutive nights along each trap line. In response to higher than expected captures of new individuals on the final day of trapping in November, the length of the trapping session in March 1993 was extended from three to five days and the number of traplines operated on each study area reduced from six to four. This strategy, however, failed to reduce the number of new individuals captured on the final day. In response, the trap density on each of the traplines operated in March was doubled for the July 1993 trapping session. As a result, 100 Sherman live-traps were operated for five consecutive nights on four traplines within each study area. For all sessions, all captured small mammals were examined, marked, sexed, weighed, and released at the site of capture.

In November 1992, a total of 1,271 individual small mammals were captured 2,083 times over 2,700 trap-nights for a trap success of $77.1 \%$ (Table 28). In March 1993, a total of 1,184 individual small mammals were captured 2,259 times over 2,979 trap-nights for a trap success of $75.8 \%$ (Table 28). In July 1993, a total of 1,668 individual small mammals were captured 3,280 times over 5,984 trap-nights for a trap success of $54.8 \%$ (Table 28). The reduction in trap success observed in July 1993 was due to the doubling of trap density on operated lines. These high trap success rates and numbers of individuals captured, suggest that the small mammal populations on the three study areas have increased since the study began. 
Table 28. Mean (SE) number of small mammals captured per trapline, total small mammals captured, total trap-nights and on burn study areas during November 1992, March 1993, and July 1993, Naval Petroleum Reserve No. 1 , Kern County, California.

\begin{tabular}{||l|l|c|c|c||}
\hline \multirow{3}{*}{ Session } & & \multicolumn{3}{|c|}{ Study Area } \\
\cline { 3 - 5 } & & Seeded Burn & $\begin{array}{c}\text { Unseeded } \\
\text { Burn }\end{array}$ & $\begin{array}{c}\text { Unburned } \\
\text { Control }\end{array}$ \\
\hline \hline \multirow{2}{*}{ November 1992 } & $\bar{x}$ (SE) Individuals & $77.8(1.4)$ & $64.8(1.4)$ & $69.2(1.0)$ \\
\cline { 2 - 5 } & Total Captures & 742 & 650 & 691 \\
\cline { 2 - 5 } & Total Trap-nights & 900 & 900 & 900 \\
\hline \multirow{3}{*}{ March 1993 } & $\bar{x}$ (SE) Individuals & $95.8(1.5)$ & $104.3(1.9)$ & $96(0.9)$ \\
\cline { 2 - 5 } & Total Captures & 754 & 759 & 746 \\
\cline { 2 - 5 } & Total Trap-nights & 998 & 982 & 999 \\
\hline \multirow{3}{*}{ July, 1993 } & $\bar{x}$ (SE) Individuals & $148.3(1.7) \mathrm{A}^{\mathrm{a}}$ & $154(1.7) \mathrm{A}$ & $114.8(2.2) \mathrm{B}$ \\
\cline { 2 - 5 } & Total Captures & 1,212 & 1,186 & 882 \\
\cline { 2 - 5 } & Total Trap-nights & 2,000 & 1,992 & 1,992 \\
\hline
\end{tabular}

${ }^{a}$ Means with the same letter within a row are not significantly different $(P>0.05)$.

The average number of individual small mammals captured was greatest on the seeded burned area in November 1992, and greatest on the unseeded burned area in March and July 1993 (Table 28). The average number of individuals captured did not differ significantly among study areas within a session, except for July 1993, when both the seeded and unseeded burned areas were significantly higher $(F=8.17$, df $=2,9$, $P=0.008$ ) than the unburned control area.

Heermann's kangaroo rats were captured most often during three trapping sessions, accounting for about $47 \%$ of all individuals captured. Short-nosed kangaroo rats and deer mice were the next most commonly captured species, accounting for $22 \%$ and $13 \%$ of all captures, respectively. The Heermann's kangaroo rat was the most abundant species on all areas for all sessions, except for the unseeded burned area in November 1992, when the short-nosed kangaroo rat was the most common species.

Results indicate that reseeding burned lands on NPR-1 does not significantly increase the abundance of small mammals. 


\subsubsection{Lagomorph Populations}

The relative abundance of lagomorphs on each of the plots was compared using data collected from pellet count plots and line-transect surveys. Fifteen pellet count plots were established adjacent to each of the six vegetation transects, for a total of 90 plots per study area. Each plot was $25-\mathrm{m}^{2}$, was permanently staked, and was cleared of all vegetation and fecal material in July 1991 . All fecal material was again removed during a pellet sampling session in July 1992. Frequency of occurrence was determined for each of the 90 plots per study area in July 1993 . Complete pellet counts were conducted on 48 of the 90 plots per study area to derive an average number of pellets per plot. In addition, four 3/4-mile line transects were established in each study area to monitor lagomorphs. Transects were walked in November 1992, March 1993, and July 1993, and the number of lagomorphs observed on each transect was recorded.

Lagomorph pellets were observed on all 270 of the plots examined, so no differences were detected in frequency of occurrence between the three study areas. Average number of pellets per plot was 268.8 (SE $=54.7$ ) on the unseeded burn area, 209.6 (SE = 46.1) on the seeded burn area, and 159.3 (SE = 34.8) on the unburned control area. Average pellet density was not significantly different $(F=1.42$, df $=$ $2,141, P=0.24)$ among the study areas.

Few lagomorphs were observed during transect surveys. In November 1992, one black-tailed jackrabbit was observed on the seeded control area, while four jackrabbits were observed on the unburned control area. In March 1993, four jackrabbits were observed on the seeded burned area, while three jackrabbits were observed on the unburned control area. In July 1993, five jackrabbits and one desert cottontail were observed on the seeded burn area, six black-tailed jackrabbits were observed on the unseeded burn area, and five black-tailed jackrabbits were observed on the unburned control area. July 1993 was the first session in which a desert cottontail was observed on any of the three study areas since monitoring began in 1990. Too few animals were observed to determine whether lagomorphs expressed a preference for any study area.

\section{$5.4 \quad$ OTHER STUDIES}

Between 1988 and 1992 the relative abundance of giant kangaroo rats and other small mammals was assessed on 10 plots along the border of Section $21 \mathrm{~S}$ and $22 \mathrm{~S}$. Giant kangaroo rats were common in Section 22S, which had a history of being used for agriculture and grazing. They were absent in undisturbed areas of Section 21S. The study assessed whether giant kangaroo rats successfully colonized plots in Section 21S from which shrubs or ground cover, or a combination of both, were removed. In FY93, data collected during the study were proofed and summarized. 
The effects of radiocollars on kit fox survival and physical condition were investigated by examining existing data. Results of this investigation were reported in technical workshops held in October 1991 and June 1992. In FY93, an executive summary was prepared primarily for distribution to FWS and the California Department of Fish and Game. This summary was co-authored with the California Energy Commission which was a primary participant in the technical workshops. Also, the results of this investigation were reported at the American Society of Mammalogists annual meeting in June 1993. Finally, a manuscript on the effects of radiocollars on kit foxes is in preparation and will be completed in FY94. 


\section{PROGRAM ASSISTANCE}

A primary objective of EG\&G/EM's participation in the Endangered Species Program at NPRC is to provide the expert advice, guidance, and assistance necessary for DOE/NPRC compliance with the 1973 Endangered Species Act. In pursuit of this objective, EG\&G/EM initiated or participated in a variety of activities during FY93. These activities included: consultation and review of the draft Supplemental Environmental Impact Statement and the Biological Opinion for NPR-1; development and reporting of progress of Endangered Species Conservation Programs; involvement in a DOE management/functional appraisal of the Endangered Species Program; and conducting site visits, briefings, and program reviews for federal and state agencies and interested civic groups.

Throughout FY93, EG\&G/EM prepared and delivered reports, statements, and information briefs concerning the Endangered Species Program and other related wildlife and habitat reclamation concerns. Work progress reports were prepared and submitted on a weekly and monthly basis. Briefings were provided to DOE and CPDN detailing EG\&G/EM's FY94 Scope of Work, field research proposals, and the Long Range Plan. EG\&G/EM also provided input to the NPRC Environmental Site Report, the FY94 Annual Operating Plan, and an NPRC Quality Improvement Team. On-site tours and briefings were also given to a variety of persons and groups, including representatives from the Kern County Wildlife Commission; individuals conducting an NPRC profitability study; students from Parkview Elementary School; an advisor and biology students from Taft High School; junior high school students involved with the Mathematics, Engineering, and Science Achievement Program; Dan Knight, an environmental analyst with DOE's Lawrence Livermore National Laboratory; and Dr. Lee Drickamer, of Southern Illinois University.

During FY93, EG\&G/EM personnel participated in a variety of local, regional, and national activities associated with wildlife research, education, conservation, habitat reclamation, and cultural resource preservation. EG\&G/EM staff attended the following: a seminar on the Endangered Species Act in Bakersfield, California; a meeting in Fresno, California sponsored by the San Joaquin Valley Endangered Species Recovery Planning Program, to coordinate research efforts dealing with listed plant species; a session of the Oil and Gas Conference in Bakersfield, California, where endangered species were discussed; a meeting on bioregional planning, organized by the San Joaquin Valley Biological Technical Committee, in Fresno, California; and a conference on DOE Environmental Safety and Health at the Strategic Petroleum Reserve Project Management Office in New Orleans, Louisiana. 
Furthermore, EG\&G/EM personnel participated in Earth Day 1993 activities held at NPRC and California State University, Bakersfield, and the NPRC Energy Conservation Awareness Week. EG\&G/EM staff coached East High School students who competed in the DOE/NPRC sponsored Science Bowl. A presentation on San Joaquin Valley wildlife was given to a class at Bessie Owens Elementary School. Additionally, EG\&G/EM staff gave presentations at the annual conference of the Western Section of The Wildlife Society, in Monterey, California; the Math, Science, and Technology Conference, in Bakersfield, California; and the American Society of Mammalogists annual meeting, in Bellingham, Washington. A draft manuscript on coyote disease prevalence at NPRC was completed and is being reviewed internally. A draft report summarizing existing data on coyotes at NPRC is being reviewed by DOE/NPRC and CPDN. A manuscript on coyote food habits at NPRC was submitted to The Southwestern Naturalist and is being reviewed by journal editors. A draft manuscript on coyote morphology and mass dynamics was submitted to DOE, Nevada Field Office for review and approval prior to being submitted to the Journal of Mammalogy.

In addition, EG\&G/EM provided support for a number of miscellaneous, unscheduled projects and events. Maps delineating the distribution of listed species at NPRC were prepared to assist the California Department of Food and Agriculture develop spraying strategies that minimized the exposure of listed species to Malathion. A map was developed illustrating various levels of petroleum development, in order to evaluate potential habitat set-aside areas. A Biological Assessment was prepared for construction and operation of a proposed cogeneration plant in Section 35R. EG\&G/EM had museum mounts made of various wildlife species at NPRC, which were used for Earth Day displays. A biologist travelled to Las Vegas to evaluate procedures to reduce employee exposure to hantavirus while handling small mammals. 


\section{PUBLICATIONS}

EG\&G Energy Measurements, Inc. 1992. Endangered Species Program, Naval Petroleum Reserves in California, Annual Report FY92. U. S. Department of Energy Topical Report. EG\&G/EM Santa Barbara Operations Report No. EGG 10617-2166. 44pp.

Scrivner, J. H., T. P. O'Farrell, K. L. Hammer. 1993. Summary and evaluation of the kit fox relocation program, Naval Petroleum Reserve \#1, Kern County, California. U. S. Department of Energy Topical Report. EG\&G/EM Santa Barbara Operations Report No. EGG 10617-2171. 88pp. 


\section{DISTRIBUTION}

U.S. Department of Energy, Naval Petroleum Reserves in California Tupman, California

D. A. Hogan, Director (2)

J. C. Killen

U.S. Department of Energy, Office of Naval Petroleum and Oil Shale Reserves

Washington, D. C.

E. R. Hunter

D. Silawsky

U.S. Department of Energy, Nevada Operations Office

Las Vegas, Nevada

Technical Information Officer

USDOE/HQ

Oak Ridge, Tennessee

OSTI (2)

U.S. Department of the Interior, Bureau of Land Management Bakersfield. California

L. Saslaw

A. Kuritsubo
U.S. Department of the Interior, Bureau of Reclamation

Fresno, California

R. Faubion

U.S. Department of the Interior, Fish and Wildlife Service

Delano, California

J. Engler

U.S. Department of the Interior, Fish and Wildlife Service

Sacramento, California

P. Cross

W. S. White

U. S. Forest Service

Goleta, California

B. Peckham

California Department of Fish \& Game Fresno, California

R. Reed

J. Single

California Department of Fish \& Game Sacramento, California

R. Schlorff (2)

J. M. Brode 
State of California Park Service

Buttonwillow, California

M. Morningstar

California Energy Commission

Sacramento, California

R. Anderson

R. B. Haussler (2)

L. Spiegel

San Joaquin Valley Endangered

Species Recovery Planning Program

Fresno. California

D. Williams (2)

Center for Natural Lands Management

Sacramento, California

S. Teresa

Bechtel Petroleum Operations, Inc.

Tupman, California

Environmental Services Department (2)

Chevron U.S.A. Production Company, Elk Hills

Bakersfield, California

J. M. Brady

H. Ordway

D. Vroom

Chevron Research and Technology Company

San Francisco. California

P. Y. O'Brien
Enterprise Advisory Services, Inc.

Tupman. California

M. Phillips

California State University

Bakersfield, California

T. Murphy

E. Winter

Carrizo Plains Macro Preserve

California Valley, California

T. Nelson

Kern County Library, Main Branch Bakersfield, California

D. Mooneyham

The Nature Conservancy

San Francisco, California

O. Pollak

L. Lozier

Smithsonian Institution

Paso Robles, California

K. Ralls

Ricks College

Rexburg. Idaho

J. H. Scrivner 
Lawrence Livermore National Laboratory

Livermore, California

T. T. Kato

EG\&G/EM LVAO

P. H. Zavattaro

Technical Information Center (2)

EG\&G/EM NV Program Office

J. A. Michael

T. P. O'Farrell

EG\&G/EM Special Technologies Program

L. A. Franks

EG\&G/EM Environmental Sciences Division

D. C. Anderson

D. A. Craghill

B. L. Cypher

N. Frost

H. J. Hill

K. A. Magargee

M. R. Otten

W. K. Ostler (5)

L. M. Parks

K. A. Spencer

G. D. Warrick

Library (20) 